
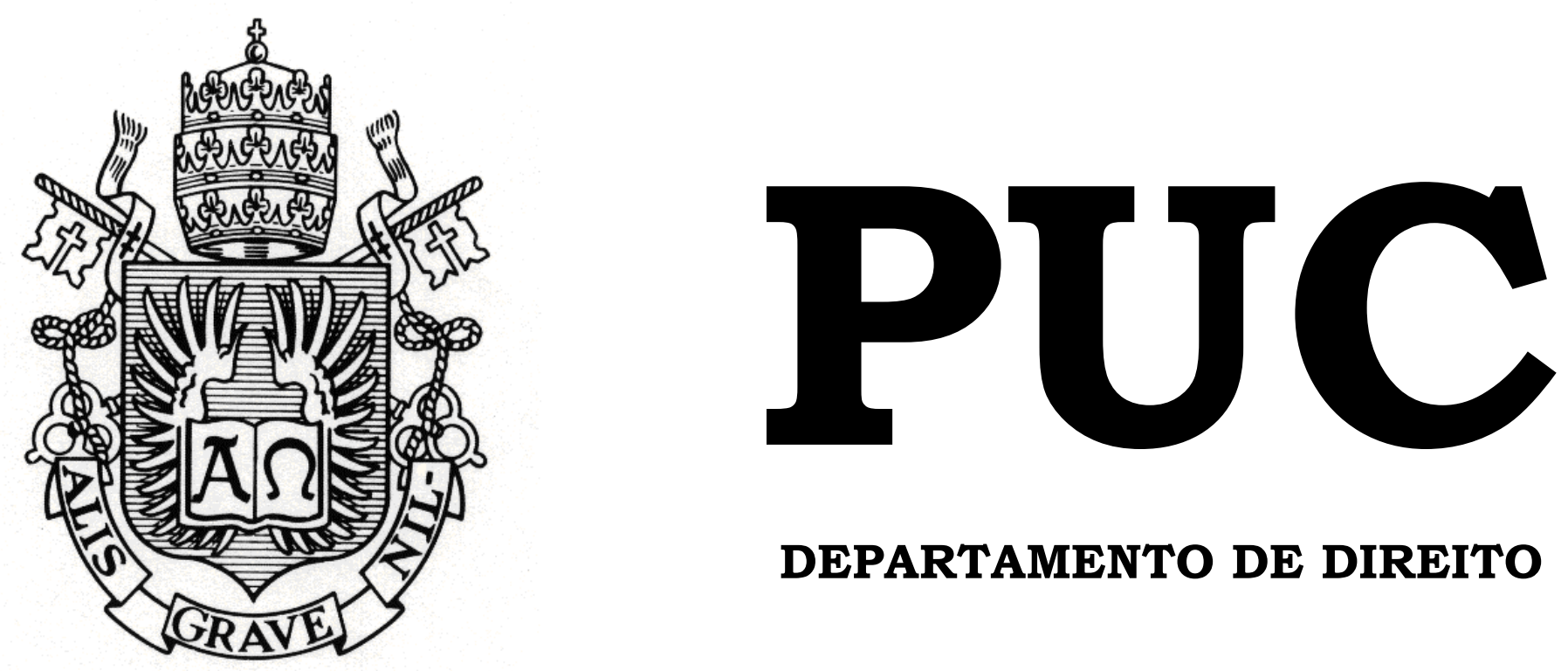

DEPARTAMENTO DE DIREITO

\title{
TESTEMUNHAS DE JEOVÁ E A RECUSA À TRANSFUSÃO DE SANGUE
}

por

GABRIELA CECCATO DALMORA

ORIENTADOR: Fábio Carvalho Leite

2018.1

PONTIFÍCIA UNIVERSIDADE CATÓLICA DO RIO DE JANEIRO

RUA MARQUÊS DE SÃO VICENTE, 225 - CEP 22453-900

RIO DE JANEIRO - BRASIL 


\section{TESTEMUNHAS DE JEOVÁ E A RECUSA À TRANSFUSÃO DE SANGUE por}

\section{GABRIELA CECCATO DALMORA}

Monografia

apresentada

ao

Departamento de Direito da Pontificia Universidade Católica do Rio de Janeiro (PUC-Rio) para a obtenção do Título de Bacharel em Direito.

Orientador: Fábio Carvalho Leite 


\section{AGRADECIMENTOS}

Primeiramente, agradeço imensamente aos meus pais, Angela e Rudi, e ao meu irmão, Vinicius, por terem me proporcionado todas as oportunidades para chegar até aqui e serem a melhor família e o melhor apoio que eu poderia ter. Eu não seria nada sem vocês;

Ao meu namorado, Hugo Ribeiro, por ser tão paciente e sempre buscar me transmitir toda calma e coragem que eu precisava para terminar esse ciclo e nunca ter me deixado desistir;

Aos meus amigos, em especial à Carla Teixeira, Ana Flávia Verri, Isabelle Costa, Daniel Luiz Fernandes, Tatiana Ponzo, Giovanna Canellas e Maria Fernanda Fernandes, que me acompanharam durante toda a faculdade e fizeram com que eu acreditasse em mim mesma com suas palavras e seus gestos de amizade, lealdade e companheirismo;

Ao meu orientador, Fabio Leite, por toda sua atenção, dedicação e incentivo para que eu desse o melhor de mim;

A todos os professores que tive o prazer de conhecer durante a faculdade, que com muita excelência me prepararam para o resto da minha vida profissional.

Muito obrigada a todos! 


\section{RESUMO}

O presente trabalho trata-se do estudo de uma polêmica conduta dos professantes da religião Testemunhas de Jeová, que consiste em recusar tratamentos de saúde que envolvam utilização de sangue, ainda que em caso de risco de vida, em razão da sua crença e respeito aos mandamentos bíblicos. A questão gera o debate entre médicos, juristas e os próprios professantes, que mantêm opiniões diferentes sobre a possibilidade de tal recusa frente a um aparente conflito entre direito à vida e a liberdade religiosa, e o objetivo do trabalho consiste em demonstrar como a aplicação conjunta de princípios norteadores da relação médico-paciente, como a dignidade da pessoa humana e os princípios bioéticos, são capazes de solucionar a questão sem que haja violação de direitos, averiguando ainda a existência de tratamentos alternativos e eficientes à utilização de sangue, bem como analisando casos mais delicados como os dos menores de idade, dos inconscientes e das gestantes.

Palavras-chave: liberdade religiosa; bioética; testemunhas de jeová; transfusão de sangue; autonomia; dignidade da pessoa humana. 


\section{Sumário}

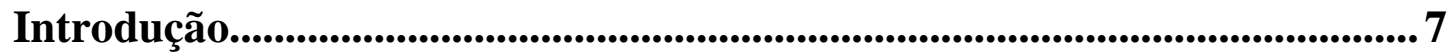

Capítulo 1 - Legitimidade da Recusa à Transfusão de Sangue por

Testemunhas de Jeová à luz dos Princípios Bioéticos.........................................9

1.1. A Liberdade Religiosa no Ordenamento Jurídico e a Objeção de

Consciência: O Caso das Testemunhas de Jeová ............................................... 9

1.2. Objeção de Consciência Sob a Ótica dos Princípios Bioéticos ........ 15

1.2.1. Princípios da Não-Maleficência e da Beneficência ........................20

1.2.2. Princípio da Autonomia................................................................ 22

Capítulo 2 - As Transfusões de Sangue e Tratamentos Alternativos.........26

2.1. Riscos inerentes às transfusões de sangue ........................................26

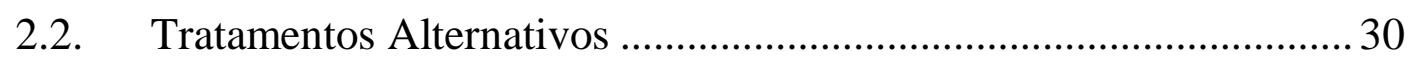

Capítulo 3 - Casos Específicos .........................................................................37

3.1. Pacientes Maiores e Capazes.............................................................. 37

3.2. Pacientes Inconscientes ................................................................. 44

3.3. Pacientes Menores de Idade e Gestantes............................................ 47

Conclusão......................................................................................................................................5 52

Bibliografia .............................................................................................................................55 


\section{Lista de abreviações}

CRFB/88 - Constituição da República Federativa do Brasil de 1988

ECA - Estatuto da Criança e do Adolescente

Art. - Artigo

STJ - Supremo Tribunal de Justiça

TRF - Tribunal Regional Federal 


\section{Introdução}

A religião existe como orientadora do modelo de vida de muitas pessoas desde os primórdios da humanidade, guiando seus professantes em muitas de suas condutas e escolhas, e seus adeptos tendem a acreditar que os ensinamentos de determinada crença têm o poder de qualificar a sua existência, que deve ser pautada por esses princípios em busca de uma vida digna e com real significado.

Esse é o caso das Testemunhas de Jeová, cujas escolhas de vida geram grandes discussões éticas e jurídicas, objetos do presente trabalho. Os professantes dessa religião cristã seguem à risca os mandamentos bíblicos, interpretados por eles como ensinamentos de Jeová, e que, se devidamente respeitados, os levarão a viver no paradisíaco Reino de Deus, um governo no céu que "substituirá os governos humanos e realizará a vontade de Deus para com a Terra"l.

Entre tais ensinamentos bíblicos estão diversas passagens que ordenam que o homem se abstenha do sangue, seja por via oral ou intravenosa, pois o sangue significa a vida, e é Jeová Deus o responsável por dar e tirar a vida dos homens, pois ele é quem rege todas as situações e soluciona todos os problemas.

Ocorre que, apesar de a liberdade religiosa ser direito fundamental da $\mathrm{CRFB} / 88$, ela nem sempre foi amplamente garantida, pois o catolicismo durante anos prevaleceu como a principal religião do Estado, sendo consagrado como a religião oficial durante a Constituição Imperial de 1824. Somente na República, com o Decreto 119-A editado em 1890, ocorreu a separação entre a Igreja e o Estado, dando abertura para uma verdadeira liberdade religiosa, mas que até hoje não se consolidou totalmente, pois os valores inerentes ao catolicismo permanecem enraizados na sociedade.

\footnotetext{
${ }^{1}$ Quais são as crenças principais das Testemunhas de Jeová? Associação Torre de Vigia de Bíblias e Tratados Disponível em: <https://www.jw.org/pt/testemunhas-de-jeova/perguntas-frequentes/crencastestemunhas-de-jeova/> Acesso em: 03 de maio de 2018.
} 
Assim, ainda existe uma grande dificuldade de se aceitar valores éticos e morais de minorias religiosas que contrastem com os da maioria. Em razão disso, o fato de a crença das Testemunhas de Jeová não permitir que se realize transfusão de sangue, nem mesmo em caso de risco de morte, causa muita indignação por grande parte da sociedade, que entende estar a vida acima de qualquer outro valor individual.

Durante anos, a postura dos médicos foi de proceder à transfusão de sangue ainda que sem autorização de seus pacientes, por meio de uma postura paternalista, em que a vontade dos médicos era considerada superior à dos indivíduos que estavam sendo tratados, tendo como justificativa o dever de proteger o paciente por meio de qualquer medida destinada a restaurar sua saúde ou prolongar a sua vida. ${ }^{2}$

Especialmente com o Código de Nuremberg de 1947, essa postura precisou ser superada, pois ele trouxe um conjunto de princípios éticos que deveriam pautar as pesquisas realizadas com pessoas, tendo em vista a descoberta de condutas extremamente desumanas durante os experimentos científicos, que foram expostos no curso dos julgamentos de guerra após o fim da Segunda Guerra Mundial.

O Código era baseado principalmente nos princípios da autonomia e do consentimento informado para autorizar a realização de experimentos com seres humanos. Além disso, outro documento muito importante e que também limitou essas pesquisas envolvendo pessoas foi o Relatório de Belmont (Belmont Report), já em 1978, que trouxe o princípio do respeito às pessoas, da beneficência e da justiça.

Como veremos, esses princípios éticos foram sofrendo algumas adaptações, sendo transformados nos que hoje chamamos de princípios bioéticos

\footnotetext{
${ }^{2}$ BARROSO, Luís Roberto. Legitimidade da recusa de transfusão de sangue por Testemunhas de Jeová. Dignidade Humana, liberdade religiosa e escolhas existenciais. Rio de Janeiro: Parecer Jurídico. 2010. p. 329.
} 
- beneficência, não-maleficência e autonomia - para que pudessem ser aplicados também nas relações entre médicos e pacientes, não só nos experimentos científicos. Assim, a discussão entre o respeito à liberdade religiosa e o direito à vida, ambos direitos fundamentais da CRFB/88, foi sendo cada vez mais pautada pelo princípio da dignidade da pessoa humana e pela bioética principialista.

Além disso, o progresso da ciência levou à descoberta de diversas formas de tratamento substitutivas ao sangue, o que demonstra a existência de alternativas em conformidade com os princípios dos religiosos dos objetores de consciência, muitas vezes com até menos riscos do que as transfusões.

A discussão é ainda mais problemática se envolvem pacientes em estado de inconsciência, sem condições de expressar sua própria vontade, assim como no caso dos menores de idade, visto que suas decisões são normalmente substituídas pelos pais ou responsáveis, discutindo-se a validade de tais vontades.

Assim, passaremos a refletir sobre as situações apresentadas, com o objetivo de se concluir como o respeito tanto à liberdade religiosa quanto à vida dessas pessoas podem conviver pacificamente, sem gerar prejuízo. 


\section{Capítulo 1 - Legitimidade da Recusa à Transfusão de Sangue por Testemunhas de Jeová à luz dos Princípios Bioéticos}

\subsection{A Liberdade Religiosa no Ordenamento Jurídico e a Objeção de Consciência: O Caso das Testemunhas de Jeová}

A liberdade religiosa foi consagrada de forma muito restrita na primeira constituição brasileira, a Constituição Imperial de $1824^{3}$.

Outorgada "em nome da Santíssima Trindade", a Carta do Império expressamente definia o Catolicismo como religião oficial do Estado 4 , determinando-se que os cultos de religiões diversas, apesar de não serem proibidos, deveriam ser realizados de forma restrita, em âmbito doméstico, vedando-se, portanto, a manifestação pública.

Tal Constituição expressa um caráter dicotômico com relação à garantia à liberdade religiosa, no momento em que permite a liberdade de crença (escolher a religião a que pretende seguir) e de consciência (escolher ter ou não uma religião), mas não assegura a sua livre manifestação por meio dos cultos, sendo uma constituição de caráter híbrido.

Como destaca Ricardo Mariano, tratava-se de uma liberdade religiosa extremamente limitada, que não constituía uma real liberdade de religião e de culto, mas "uma espécie de extensão da liberdade de consciência religiosa" pois restringia a atividade dos acatólicos, e, além disso, até mesmo os católicos

\footnotetext{
${ }^{3}$ Art. 179. A inviolabilidade dos Direitos Civis, e Politicos dos Cidadãos Brazileiros, que tem por base a liberdade, a segurança individual, e a propriedade, é garantida pela Constituição do Imperio, pela maneira seguinte.

V. Ninguem póde ser perseguido por motivo de Religião, uma vez que respeite a do Estado, e não offenda a Moral Publica.

${ }^{4}$ Art. 5. A Religião Catholica Apostolica Romana continuará a ser a Religião do Imperio. Todas as outras Religiões serão permitidas com seu culto domestico, ou particular em casas para isso destinadas, sem fórma alguma exterior do Templo.

5 MARIANO, Ricardo. Secularização do Estado, liberdades e pluralismo religioso. 2002. Disponível em: < http://www.equiponaya.com.ar/congreso2002/ponencias/ricardo_mariano.htm>. Acesso em: 23 de Abril de 2018.
} 
se viam de certa forma prejudicados, já que o Poder Político controlava rigorosamente a Igreja Católica, que, apesar de possuir diversos bônus por ser a religião oficial do Estado, por este mesmo motivo acabava sofrendo regulações extremas.

O Estado eminentemente católico assim permaneceu até pouco depois da proclamação da república, em 1889, com a edição do Decreto nº 119-A, redigido pelo jurista baiano em 07/01/1890, que finalmente estabeleceu a separação entre Estado e Igreja.

Com a promulgação da constituição republicana, em 1891, essa separação prevaleceu, mas isso não significa que a liberdade religiosa fosse ampla. Isso porque era livre apenas a crença, mas não a objeção de consciência, como dispõe o § 28 do art. 72, ao estabelecer que nenhum cidadão poderia, por motivos de crença religiosa, eximir-se de seus deveres cívicos, e esse aspecto da liberdade religiosa é objeto de muitas discussões atualmente.

Foi somente na Constituição de 1946 que a escusa de consciência foi prevista, no artigo 141, $\S 8^{\circ}$, permitindo a existência de obrigação, encargo ou serviço alternativos em caso de recusa de se praticar a conduta originalmente imposta, por motivos religiosos, mas ainda assim não exime de pena em caso de descumprimento das penas substitutas ${ }^{6}$.

A Constituição atualmente em vigor, promulgada em 1988, assegura, no inciso VI do art. $5^{\circ}$ a inviolabilidade da liberdade de crença e a de consciência, assim como permite cultos religiosos de qualquer religião, até mesmo assumindo o dever de proteção aos locais em que são realizados. ${ }^{7}$

Com relação à objeção de consciência, a CRFB/88 seguiu o modelo de 1946, dispondo no inciso VIII do art. $5^{\circ}$ que "ninguém será privado de direitos

\footnotetext{
6“Por motivo de convicção religiosa, filosófica ou política, ninguém será privado de nenhum dos seus direitos, salvo se a invocar para se eximir de obrigação, encargo ou serviço impostos pela lei aos brasileiros em geral, ou recusar os que ela estabelecer em substituição daqueles deveres, a fim de atender escusa de consciência."

7 VI - é inviolável a liberdade de consciência e de crença, sendo assegurado o livre exercício dos cultos religiosos e garantida, na forma da lei, a proteção aos locais de culto e a suas liturgias;
} 
por motivo de crença religiosa ou de convicção filosófica ou política, salvo se as invocar para eximir-se de obrigação legal a todos imposta e recusar-se a cumprir prestação alternativa, fixada em lei”.

É nesse debate em relação ao direito à objeção de consciência que se encontra a grande problemática com relação a certas religiões hoje professadas no Brasil, ressaltando-se, aqui, aquela pregada pelas Testemunhas de Jeová, que tem ganhado grande destaque devido às suas concepções éticas e morais.

As Testemunhas de Jeová consistem em uma religião cristã, com origem nos Estados Unidos no século XIX, consistindo hoje me cerca de 8 milhões de professantes no mundo, sendo que o Brasil é o terceiro país com maior número de seguidores ${ }^{8}$.

O próprio nome já define o propósito desse fiel, sendo um grupo de pessoas que "relata fatos com conhecimento pessoal e direto, ou proclama conceitos ou verdade dos quais está convicta", pregando a palavra de Deus pelo mundo, o que se dá hoje em cerca de 240 países.

Jeová significa Deus, o Criador de todas as coisas, e para seus seguidores a sua palavra é a verdade absoluta, e respeitá-la significa ter uma garantia de experimentar a vida eterna, fazendo com que preguem por toda a sociedade o testemunho de Jeová, como assim preceituam:

As Testemunhas de Jeová acreditam que "toda a Escritura é inspirada por Deus e proveitosa". (2 Timóteo 3:16) Usamos a Bíblia como um guia prático para aprender sobre o Criador e para ter uma vida significativa.

A Bíblia diz: "Que as pessoas saibam que tu, cujo nome é Jeová, somente tu és o Altíssimo sobre toda a terra." (Salmo 83:18) Por isso, adoramos somente a Jeová Deus e, como suas testemunhas, nos esforçamos em divulgar seu nome. - Isaías 43:10-12. ${ }^{10}$

\footnotetext{
${ }^{8}$ Quem são as Testemunhas de Jeová? Revista A Sentinela, São Paulo: Associação Torre de Vigia de Bíblias e Tratados, 2015, vol.136, n.17.p. 4.

9 ASSOCIAÇÃO TORRE DE VIGIA DE BÍBLIAS E TRATADOS. Testemunhas de Jeová: Proclamadores do Reino de Deus. São Paulo, 1993. p. 12.

${ }^{10}$ Quem são as Testemunhas de Jeová? Op Cit., 5.
} 
Em razão da estrita obediência aos ensinamentos bíblicos, as Testemunhas de Jeová alegam buscar respeitar ao máximo a lei, desde que ela não conflite com sua neutralidade, em virtude de uma "orientação dada por Jesus aos cristãos de 'não fazer parte do mundo "'"l , o que significa não praticar atos por Ele condenados, mesmo que em conformidade com o ordenamento jurídico a que estão sujeitos, motivo pelo qual se recusam, por exemplo, a prestar serviços militares, por serem contrários à guerra e ao uso das armas.

É a partir da sua interpretação a tais ensinamentos que seus adeptos também não aceitam qualquer tratamento de saúde que envolva a transfusão de sangue, e sua justificativa é principalmente pautada nas passagens bíblicas dispostas em Gênesis 9:3-4, Levítico 17:14 e Atos 15:19, 20, 18-2912.

Apesar de tais passagens se referirem ao não uso do sangue como alimento, as Testemunhas de Jeová explicam sua extensão ao seu uso intravenoso, a partir da seguinte analogia:

Será que o mandamento de se abster de sangue inclui transfusões de sangue? Sim. Para ilustrar: digamos que um médico lhe recomendasse abster-se de álcool. Será que isso significaria simplesmente que você não deveria beber álcool, mas poderia injetá-lo nas veias? Claro que não! Da mesma forma, abster-se de sangue quer dizer não introduzilo de modo algum no corpo. Ou seja, o mandamento de se abster de sangue significa que não devemos permitir que ninguém injete sangue nas nossas veias. ${ }^{13}$

\footnotetext{
11 Ibid. p. 4.

${ }^{12}$ Gênesis 9:3 e 4. "Tudo o que se move e possui vida vos servirá de alimento, tudo isso eu vos dou, como vos dei a verdura das plantas. Mas não comerei a carne com tua alma, isto é, o sangue."

Levítico 17:14. "Pois a vida de toda a carne é o sangue, e eu disse aos filhos de Israel: "Não comereis o sangue de carne alguma, pois a vida de toda carne é o sangue, e todo aquele que o comer será exterminado."

Atos 15:19 e 20. "Eis porque, pessoalmente, julgo que não se devam molestar aqueles que, dentre os gentios, se convertem a Deus. Mas se lhes escreva que se abstenham do que está contaminado pelos ídolos, das uniões ilegítimas, das carnes sufocadas e do sangue."

Atos 15:28 e 29: "De fato, pareceu bem ao Espírito Santo e a nós não vos impor nenhum outro peso além destas coisas necessárias: que vos abstenhais das carnes imoladas aos ídolos, do sangue, das carnes sufocadas, e das uniões ilegítimas. Fareis bem preservando-vos destas coisas. Passai bem”.

${ }^{13}$ ASSOCIAÇÃO TORRE DE VIGIA DE BÍBLIAS E TRATADOS. O que a Bíblia realmente ensina? São Paulo: Cesário Lange, 2005, p. 130.
} 
A sacralidade do sangue, para essa religião, é que ele significa a própria vida, e o único responsável por dar início ou fim à vida é Jeová Deus, devendo o ser humano abster-se de meios que possam "driblar" a sua existência. É assim que as Testemunhas de Jeová explicam seu entendimento:

Depois que Caim matou seu irmão, Abel, Jeová lhe disse: "O sangue do seu irmão está clamando a mim desde o solo" (Gênesis 4:10) Quando Deus falou do sangue de Abel, ele referia-se à vida de Abel. Caim havia tirado a vida de seu irmão e tinha de ser punido. Era como se o sangue, ou a vida, de Abel clamasse a Jeová por justiça. A relação entre vida e sangue ficou de novo evidente depois do Dilúvio dos dias de Noé. Antes do Dilúvio, as pessoas comiam apenas frutas, vegetais, cereais e nozes. Depois do Dilúvio, Jeová disse a Noé e seus filhos: "Todo animal que se move e que está vivo pode servir-lhes de alimento;" No entanto, Deus impôs esta restrição: "Somente não comam a carne de um animal com seu sangue, que é a sua vida." (Gênesis 1:29; 9:3, 4) Obviamente, Jeová estabeleceu uma relação bem estreita entre a vida e o sangue de uma criatura. ${ }^{14}$

Mas não é apenas o ponto de vista religioso o capaz de justificar sua escolha em se abster do sangue, tendo em vista que existem também as questões científicas, pelos riscos que as transfusões de sangue são capazes de causar e a existência de alternativas até mesmo mais seguras e muito eficientes, bem como as questões éticas, que dizem respeito à autonomia do ser humano e à liberdade de consciência.

Essa questão tem sido alvo de muitas controvérsias judiciais e doutrinárias, normalmente tentando-se resolver o conflito simplesmente ponderando-se o direito à liberdade religiosa e o direito à vida, em busca de se chegar a um resultado que justifique a legitimidade ou não da objeção de consciência, o que não se mostra o bastante, como preceitua o professor Fabio Leite:

O dilema, tal como apresentado, entre o direito à vida, de um lado, e a liberdade religiosa, de outro, resulta em um falso dilema, pois, colocadas as questões nestes termos, a solução é oferecida a priori, em favor da vida, e não a posteriori, como

\footnotetext{
${ }^{14}$ Ibid. p. $128-129$.
} 
resultado de uma ponderação entre os bens e valores em jogo e da análise das peculiaridades do caso concreto. ${ }^{15}$

Acontece que a religião existe principalmente para dar o próprio significado à vida, é um direito intrínseco à pessoa e que baseia todo o seu modo de viver, suas escolhas, sua forma de enxergar o mundo e o que acontece em sua volta, o que faz com que seja ainda mais difícil colocar os dois direitos em extremidades opostas.

Historicamente, sob a perspectiva do médico, a proteção da vida se dá apenas no aspecto biológico, mediante uma atuação tendente a preservar a vida a qualquer custo. Já sob a perspectiva jurídica e moral, a vida é mais do que isso, é uma existência com dignidade, com autonomia, com poder de se autodeterminar, com liberdade.

O Estado Democrático de Direito deve exercer uma posição tanto positiva quanto negativa em relação às liberdades, incluindo a religiosa. A primeira consiste na figura do Estado realizador de direitos e garantias, e a segunda significa a não interferência na esfera privada de cada um, desde que não esteja ocorrendo a violação dos direitos de terceiros.

A nossa própria Constituição dispõe, em seu art. $3^{\circ}$, serem objetivos da República Federativa do Brasil a construção de uma sociedade livre, justa e solidária (inciso I), assim como o bem-estar de todos, sem qualquer tipo de preconceitos e discriminações (inciso IV), sempre tendo como fundamento para sua proteção não a vida em si, mas a dignidade da pessoa humana, conforme dispõe o art. $1^{\circ}$, inciso III da CRFB/88, que serve como base para toda a atividade do Estado e da própria sociedade.

É de se ressaltar, aliás, que o significado de dignidade da pessoa humana não é um conceito fixo, tratando-se de um instituto em constante mudança, pois tanto os valores sociais quanto os valores individuais mudam, mas ela é

\footnotetext{
${ }^{15}$ LEITE, Fábio Carvalho. Estado e Religião: A Liberdade Religiosa no Brasil. Curitiba: Juruá, 2014. p. 432
} 
intransferível e inalienável, razão pela qual, seja qual for o sentido de uma vida digna para determinado indivíduo, a dignidade sob sua perspectiva é inerente a ele, e não pode ser retirada de si.

Deste modo, na situação fática em questão - da recusa ao tratamento com sangue pelas Testemunhas de Jeová - tão presente nos dias de hoje, a análise entre direito à vida e direito à liberdade religiosa, por si só, não é capaz de nos dar soluções suficientes, tendo o Direito a possibilidade de se valer de outras áreas, hoje em ascensão, que podem, a partir de sua principiologia, dar uma maior margem de entendimento e um resultado mais justo às questões postas em discussão.

Deste modo, entende-se adequado à resolução do conflito de ordem religiosa a que os Testemunhas de Jeová são submetidos a aplicação dos Princípios Bioéticos, os quais se passa agora a conceituar e explicar a sua adequação ao presente caso.

\subsection{Objeção de Consciência Sob a Ótica dos Princípios Bioéticos}

Os desenvolvimentos da tecnologia nas áreas de saúde abriram o debate tanto acerca dos benefícios quanto dos problemas que a intervenção científica pode causar na pessoa humana, principalmente no que se refere à vida, à integridade física, à identidade genética e de gênero, à reprodução humana, entre outras questões médicas atuais.

A tendência nos hospitais é a de se respeitar a escolha do paciente no que se refere aos tratamentos aos quais aceita ou não ser submetido, exceto em casos em que haja eminente risco de vida, o que normalmente faz com que os médicos utilizem procedimentos mesmo contra a vontade do paciente. 
É essa a redação da Resolução 1.021/80 do Conselho Federal de Medicina ${ }^{16}$, segundo o qual, havendo risco de vida, o médico realizará a transfusão de sangue, independentemente do consentimento do paciente ou de seus representantes.

Nesses casos, deparamo-nos com um aparente conflito entre direitos fundamentais expressamente elencados na nossa Constituição. No caso das Testemunhas de Jeová, ele se dá entre o direito à vida e o direito à liberdade religiosa que, como já explicado, é de fato apenas aparente.

No caso dos pacientes Testemunhas de Jeová, o que eles esperam é um tratamento eficaz e isento de sangue, em conformidade com os seus princípios e que lhes permita permanecer em conformidade com suas crenças, ainda que sua vida tenha que ter um fim para que vivam eternamente no paraíso guiado por Jeová.

Por outro lado, em razão de seu juramento, os médicos agem sempre em prol da vida, sendo a sua profissão toda direcionada a garantir a saúde e proteção de quem quer que esteja em seus cuidados, principalmente em casos de urgência e até mesmo pelo constante receio de serem responsabilizados por atos contrários ao ditado pela ética médica.

Com efeito, a Bioética age como uma forma de, se não resolver, ao menos amenizar esses conflitos da relação médico-paciente, com o objetivo de trazer uma solução justa e em conformidade com a vontade pessoal dos pacientes Testemunhas de Jeová, auxiliando na interpretação constitucional mais adequada à defesa de sua dignidade humana.

No final da Segunda Guerra Mundial, os julgamentos do Tribunal de Nuremberg deixaram expostas ao mundo todo as atrocidades cometidas durantes a guerra, em especial pelas experiências desumanas realizadas na Alemanha

\footnotetext{
162 - O paciente se encontra em iminente perigo de vida e a transfusão de sangue é a terapêutica indispensável para salvá-lo.

Em tais condições, não deverá o médico deixar de praticá-la apesar da oposição do paciente ou de seus responsáveis em permiti-la
} 
nazista, tendo como um ponto relevante e que causou muito espanto na sociedade, o fato de que a maioria dos réus a serem julgados eram médicos. Assim lembra o cardiologista José Agostinho Lopes:

Mais grave ainda, a humanidade, perplexa, vê, assentados no banco dos réus, 23 pessoas acusadas de crimes de guerra e contra a humanidade, e entre eles 20 são médicos. Desses 23, 16 são declarados culpados, sendo sete condenados à morte. Esse contexto evidencia que a ética profissional dos médicos, em princípio beneficente, não é sempre confiável, tampouco a consciência moral do investigador é suficiente como limite seguro para o controle da experimentação. Abalam-se simultaneamente o paternalismo médico e a suposta neutralidade da ciência. ${ }^{17}$

Em uma época de constantes e valiosas descobertas científicas, a preocupação com o bem-estar dos indivíduos submetidos aos experimentos era quase nula, pois o objetivo era chegar ao maior avanço da ciência para o futuro, sem que se atentasse aos sofrimentos físicos e psíquicos que essa sede por resultados causava aos seres humanos, surgindo a necessidade de um limite a essas condutas.

Assim, no mesmo ano dos julgamentos de Nuremberg, em 1947, o tribunal elaborou o Código de Nuremberg, um documento que uniu diversos princípios éticos a fim de regular a prática dos médicos na realização de experimentos científicos, baseando-se principalmente nos princípios do consentimento informado, da autonomia da vontade do paciente e da dignidade da pessoa humana, para que ninguém seja submetido a qualquer experimento sem saber exatamente do que se trata e sem que seja de sua livre vontade participar.

Logo depois, em 1948, em busca de fortalecer os direitos e as liberdades de todos os indivíduos, do a Declaração Universal de Direitos Humanos dispôs, no art. $1^{\circ}$, que "Todos os homens nascem livres e iguais em dignidade e em

\footnotetext{
${ }^{17}$ LOPES, José Agostinho. Bioética - uma breve história: de Nuremberg (1947) a Belmont (1979).
} Revista Médica de Minas Gerais, 2014, vol. 24. n 2. p. 265. 
direitos", e no art. $3^{\circ}$ que "Todo indivíduo tem direito à vida, à liberdade e à segurança pessoal".

Todos esses documentos foram extremamente importantes para a afirmação do ser humano como ser racional dotado de sua própria autonomia, e que nem mesmo a ciência poderia avançar tanto a ponto de interferir em sua esfera privada.

Do mesmo modo, como preceitua Maria Helena Diniz, vindo de um período de progresso cientifico desenfreado, "a bioética emerge como novo domínio da reflexão que considera o ser humano em sua dignidade e as condições éticas para uma vida humana digna" "18, ressaltando, assim, a elevação do homem como sujeito de direitos e gerenciador da própria vida:

\begin{abstract}
A bioética é personalista, por analisar o homem como pessoa ou como "eu", dando valor fundamental à vida e à dignidade humanas, não admitindo qualquer intervenção no corpo humano que não redunde no bem da pessoa, que sempre será um fim, nunca um meio para obtenção de outras finalidades. ${ }^{19}$
\end{abstract}

O termo "bioética" se tornou popularizado a partir das obras de Van Potter, que a definia como uma ponte que ligava o conhecimento biológico e os valores humanos, tendo como foco de suas pesquisas o meio ambiente equilibrado e a preservação da vida. ${ }^{20}$

Esse conceito foi sendo estendido e adaptado por diversos autores ao longo dos anos. Em 1978 foi publicado, pela Comissão Nacional para a Proteção dos Seres Humanos em Pesquisa Biomédica e Comportamental, o Belmont Report, um relatório indicando determinados princípios que deveriam pautar as relações médico-paciente, a fim de garantir esse respeito ao indivíduo submetido à ciência e desenfrear os males causados pelo avanço tecnológico:

\footnotetext{
${ }^{18}$ DINIZ, Maria Helena. O estado atual do biodireito. $10^{\text {a }}$ ed.. São Paulo: Saraiva, 2017. p. 30

${ }^{19}$ Ibid. p. 31.

${ }^{20}$ NAMBA, Edison Tetsuzo. Manual de Bioética e Biodireito. $2^{\text {a }}$ ed.. São Paulo: Atlas, 2015. p. 9.
} 
Nele foram eleitos três princípios orientadores básicos para a pesquisa envolvendo seres humanos: a) respeito pelas pessoas; b) beneficência; c) justiça. $\mathrm{O}$ respeito pelas pessoas com dois pressupostos éticos: a) os indivíduos devem ser tratados como agentes autônomos; b) os com autonomia reduzida (vulneráveis) têm direito à proteção. Institucionaliza-se assim o consentimento informado. A beneficência, de tradição hipocrática, também comporta duas regras complementares: a) não fazer o mal; b) propiciar o máximo de benefícios com o mínimo de danos possíveis. A justiça impõe cuidado na seleção e equidade em relação aos sujeitos das pesquisas. Estavam eleitos os parâmetros éticos que deveriam orientar a experimentação com seres humanos. ${ }^{21}$

\section{Em 1979, Beauchamp e Childress publicaram o livro Principles of} Biomedical Ethics. Nela, os princípios dispostos no Belmont Report foram atualizados para serem aplicados também à assistência clínica, e não somente no caso de experimentos humanos:

Nesse texto, o princípio de respeito pelas pessoas foi substituído pelo da autonomia e o da beneficência foi desdobrado em beneficência e não maleficência. Desse modo, consagraram-se os seguintes princípios: a) o da autonomia, privilegiando a decisão do paciente; b) os de beneficência e não maleficência, imputados aos profissionais de saúde; c) e o de justiça, especificamente distributiva, voltado especialmente para as instituições de saúde e a sociedade no tratamento das questões relativas à vida e saúde dos seres humanos. ${ }^{22}$

Essa obra consagrou o chamado "principialismo", que, como explica Clotet $^{23}$, surgiu da necessidade de uma teoria prática e acessível para solução de conflitos gerada pelo forte pluralismo ético e diversidade de valores morais, que tornam difícil uma solução harmônica quando nos referimos a assuntos como doação de órgãos, aborto, escolha do momento para morrer, entre outros que geram conflitos éticos de caráter biomédico.

Para buscar uma solução justa para o caso em questão, da recusa à transfusão de sangue por questões religiosas, passaremos à análise dos princípios da não-maleficência, da beneficência e da autonomia do paciente, por entender serem os mais adequados e passíveis de levar à uma solução justa à situação.

\footnotetext{
${ }^{21}$ LOPES, José Agostinho. Op. Cit., p. 271.

${ }^{22}$ Ibid. p. 272.

${ }^{23}$ CLOTET, Joaquim. Bioética: uma aproximação. Porto Alegre: EDIPUCRS, 2003, p. 61.
} 


\subsubsection{Princípios da Não-Maleficência e da Beneficência}

No Brasil, em especial após a promulgação da CRFB/88, a proteção dos direitos fundamentais e a busca pelo respeito ao indivíduo como ser humano fizeram com que, também nas áreas médicas, o homem fosse tratado como dono de seu próprio corpo e de suas escolhas, acarretando no progresso da chamada emancipação do paciente, em que se reconhece o paciente como pessoa detentora de valores fundamentais próprios e determinados. ${ }^{24}$

Ocorre que nem sempre foi assim, visto que até antes do período pósguerra, do Código de Nuremberg, os médicos eram guiados majoritariamente pelos princípios da beneficência e da não-maleficência da chamada ética hipocrática, que hoje, apesar de ainda existirem, estão sendo sobrepostos por outras diretrizes e ouros princípios éticos.

A não-maleficência - primum non nocere - consiste em primeiro não prejudicar o paciente. Assim, os médicos devem utilizar a sua posição para auxiliar o indivíduo - beneficência, que será vista a seguir - e, caso assim não seja possível, devem ao menos evitar que se cause qualquer dano a ele.

Esse princípio destaca que há diversos tratamentos que podem ser desnecessários à recuperação de saúde do paciente, e, muitas vezes, são apenas formas desproporcionais de chegar a um resultado. Até porque, é preciso ponderar os riscos e os benefícios que o indivíduo teria com aquele procedimento, sendo que o respeito às crenças e aos valores pessoais de cada um pode ser mais benéfico ao paciente do que um tratamento aparentemente mais adequado, que pode gerar muito sofrimento físico e psicológico que o indivíduo não está disposto se submeter.

A beneficência, por sua vez, significa utilizar todos os meios possíveis para alcançar a saúde do paciente, visando seu bem-estar. Clotet e Kipper destacam que, para alguns filósofos, ela é uma expressão da benevolência, e eles

\footnotetext{
${ }^{24}$ Ibid. p. 17
} 
se dedicaram a estudar e defende-la como uma forma de criticar a natureza extremamente egoísta do ser humano apontada por Thomas Hobbes, ressaltando que o homem nutre também sentimentos de compaixão pelos outros, impulsionando a prática do bem. ${ }^{25}$

Ocorre que, antigamente, esse princípio era observado na medida em que, em razão da confiança que a sociedade depositou na capacitação dos médicos em garantir a vida e a saúde de seus pacientes, eles tinham como foco principal a proteção da vida a todo custo, adotando assim uma postura paternalista, em que as decisões eram tomadas sem que o paciente a ser tratado pudesse invocar conviç̧ões e vontades que fossem contrárias ao que a ética médica ordenava.

Assim, o profissional de saúde sentia-se no direito interferir sobre a autonomia do paciente, justificando suas ações no "bem-estar, alegria, necessidades, interesses ou valores da pessoa que está sendo tratada" ${ }^{26}$, ainda que esses critérios não tivessem para o paciente mesmo sentido que tinha para o médico e para o restante da sociedade.

Sem dúvida alguma, o bem-estar do paciente ainda é e sempre vai ser o objetivo principal de um profissional da saúde. Até hoje, o juramento hipocrático realizado pelos médicos honra esses princípios, e assim dispõe: "Aplicarei os regimes para o bem do doente segundo o meu poder e entendimento, nunca para causar dano ou mal a alguém”.

Hoje, no entanto, a situação mudou. Os direitos do paciente têm sido cada vez mais reconhecidos, e ele faz - ou deveria fazer - parte da escolha acerca do melhor tratamento para o seu caso, quando isso for possível, visando sempre respeitar as suas próprias convicções e julgamentos, após ter sido devidamente esclarecido sobre suas possibilidades.

\footnotetext{
${ }^{25}$ KIPPER, Délio José; CLOTET, Joaquim. Princípios da Beneficência e Não-maleficência. In: COSTA, Sérgio Ibiapina Ferreira et al. Iniciação à bioética. Brasília: Conselho Federal de Medicina, 1998. p. 37-51.

26 MUÑOZ, Daniel Romero; FORTES, Paulo Antônio Carvalho. O princípio da autonomia e o consentimento livre e esclarecido. Ibid. p. 53-70.
} 
Muito se diz que a beneficência deu lugar à autonomia, o que não ocorreu de fato. Na verdade, o conceito de beneficência vem sofrendo modificações ao longo dos anos. Ela continua a significar fazer o bem, no entanto, esse bem deve ser uma conduta benéfica de acordo com o paciente, e não apenas com o médico, havendo uma superação do chamado paternalismo médico. Se o bem para uma pessoa é a realização ou não de determinados tratamentos, respeitar a autonomia do paciente é agir com beneficência, tendo os dois princípios, aplicados conjuntamente, chegado ao melhor resultado.

\subsubsection{Princípio da Autonomia}

Como destacado acima, o princípio da autonomia pressupõe a atuação beneficente do médico, na medida em que, respeitando as escolhas do indivíduo, dono do próprio corpo e da própria vida, o bem estará sendo feito para aquela pessoa, que é a destinatária da intervenção médica e a principal pessoa da relação médica. Mas o que é, de fato, o princípio da autonomia e o que significa respeitálo?

Autonomia consiste na liberdade individual que cada pessoa tem de se autodeterminar - nas suas escolhas ou em seus atos - e definir seu próprio modo de viver dignamente, e respeitar essa autonomia significa não agir em desfavor dos valores que ela propõe, ainda que estes não sejam os mesmos do resto da sociedade. Nesse sentido se posicionam Muñoz e Fortes, que defendem que:

Respeitar a autonomia é reconhecer que ao indivíduo cabe possuir certos pontos de vista e que é ele quem deve deliberar e tomar decisões segundo seu próprio plano de vida e ação, embasado em crenças, aspirações e valores próprios, mesmo quando divirjam daqueles dominantes na sociedade ou daqueles aceitos pelos profissionais de saúde. ${ }^{27}$

${ }^{27}$ Ibid. p. 58 . 
O princípio da dignidade da pessoa humana está completamente relacionado ao respeito à autonomia individual, sendo preciso respeitar o pluralismo ético e moral que vem crescendo cada dia mais e reconhecer o direito que cada pessoa tem de autonomamente realizar suas escolhas.

A própria Constituição Federal, além de garantir os direitos fundamentais à liberdade de crença, de consciência, de culto e de expressão, dispõe, em seu inciso II do art. $5^{\circ}$, que "ninguém será obrigado a fazer ou deixar de fazer alguma coisa senão em virtude de lei”.

O que se observa é que, da mesma forma que não existe dispositivo algum no ordenamento jurídico que obrigue os médicos a realizarem tratamentos contra a vontade do paciente, também não há previsão para puni-los caso o façam em desrespeito à crença individual daquele submetido ao procedimento, o que deixa o ser humano livre para comportar-se da forma que quiser.

Assim, a problemática é grande pura e simplesmente pela falta de previsão legal expressa. No entanto, isso não significa que a situação não tenha solução, e a dignidade da pessoa humana como fundamento máximo do nosso ordenamento jurídico atual é a principal saída para a questão.

A Declaração Universal dos Direitos Humanos ${ }^{28}$ coloca o ser humano como ser dotado de dignidade, razão e consciência, devendo respeitar uns aos outros com espírito de fraternidade, o que revela a aspiração pela compaixão e a crescente busca pela autonomia de cada um, que pode gerir sua vida de acordo com suas próprias convicções.

O ser humano não existe apenas no plano físico, devendo-se considerar que o seu grande diferencial em relação às demais espécies é o seu poder intelectual, a sua capacidade de racionar e, partir disso, entender e seguir crenças que considerar serem as mais adequadas ao seu modo de viver.

\footnotetext{
${ }^{28}$ Artigo $1^{\text {o: }}$ "Todos os seres humanos nascem livres e iguais em dignidade e em direitos. Dotados de razão e de consciência, devem agir uns para com os outros em espírito de fraternidade."
} 
No entanto, para que essa autonomia seja corretamente exercida e protegida, ela deve ser condicionada ao consentimento informado, ou consentimento livre e esclarecido, assim explicado:

Quando se cuida da informação a que tem direito o paciente, trata-se de se garantir a ele o poder de decidir sobre o próprio destino, permitindo, ou não, que o profissional da saúde realize em seu favor determinado procedimento (exercendo o paciente o que se convencionou chamar de consentimento informado); para que possa tomar essa decisão, necessitará o paciente de informações pormenorizadas sobre as hipóteses diagnósticas de seu problema, bem como acerca dos procedimentos destinados à complementação ou à confirmação desses diagnósticos, os tratamentos possíveis (e suas consequiências) e o prognóstico. ${ }^{29}$

Não raramente encontramos ações indenizatórias contra médicos em virtude da falta de informação dada por ele ao proceder a determinados tratamentos, o que induz o paciente ao erro e o leva a concordar com procedimentos acerca dos quais nem ao menos sabia as possíveis consequências.

Não se pode esquecer, conforme salienta o Dr. Osamu Muramoto, que apesar de ser garantida a liberdade de consciência, não significa que esta esteja isenta de pressões, e os pacientes Testemunhas de Jeová muitas vezes sofrem essa pressão dos familiares e da comunidade cristã, não se excluindo a possibilidade de suas escolhas pessoais serem coagidas e, muitas vezes, desinformadas e equivocadas. ${ }^{30}$

A informação repassada ao paciente, portanto, deve ser livre da presença e influência de terceiros, bem como deve ser adequada e completa, sem que haja lacunas de interpretação que levem a equívocos e sejam fatais no momento em que uma pessoa expressa, por meio de sua própria liberdade, a sua escolha definitiva.

\footnotetext{
${ }^{29}$ LEVI, Guido Carlos; BARROS, Antonio Ozório Leme de. Ética clínica: a AIDS como paradigma. In: COSTA, Sérgio Ibiapina Ferreira et al.. Op. Cit., p. 285-294.

${ }^{30}$ MURAMOTO, Osamu. Bioethics of the refusal of blood by Jehovah's Witnesses: Part 2. A novel approach based on rational non-interventional paternalism. J Med Ethics, 1998, Oct. 24. p. 296.
} 
No momento em que se chega à conclusão que um paciente precisa de transfusão de sangue para ter sua saúde restaurada, sendo ele um indivíduo adulto, capaz e consciente (as demais hipóteses serão tratadas oportunamente), todas as eventuais consequências dos seus atos precisam ser detalhadamente repassadas pelo médico.

Até porque, estando esse paciente adequadamente informado de seus riscos, ele tem o direito de determinar o destino de sua própria existência, visto que a sua crença é o que lhe dá motivo para viver, e desrespeitá-la pode ser muito mais doloroso e antiético do que aceitar a morte, já que a vida que teria à sua frente seria completamente alheia à tudo aquilo que sempre acreditou e buscou obedecer.

Mas além da questão religiosa, a transfusão de sangue apresenta ainda diversos riscos à saúde, e todos eles devem ser expostos para que cada indivíduo chegue às suas próprias conclusões acerca do seu corpo e da sua vida, pois é razoável que ninguém seja submetido a qualquer tratamento que lhe causa riscos desnecessários e, assim, possa decidir a melhor forma de proceder. 


\section{Capítulo 2 - As Transfusões de Sangue e Tratamentos Alternativos}

\subsection{Riscos inerentes às transfusões de sangue}

A hemoterapia, que consiste na utilização de sangue ou de algum de seus componentes para determinados tratamentos de saúde, é considerada por grande parte das equipes médicas como a melhor ou uma das melhores formas de recuperação para pacientes hemofílicos.

Apesar de o método ser historicamente bastante utilizado para salvar a vida de pacientes, é preciso lembrar que a transfusão sanguínea não consiste em uma garantia, em uma certeza para o paciente, pois, assim como os outros métodos de tratamento, trata-se de uma tentativa.

A utilização de transfusão pode até mesmo ter um resultado inverso do que se procura, havendo casos em que ela reduz a probabilidade de o paciente viver, em vez de salvar sua vida, existindo comprovação cientifica de uma "correlação direta, estatisticamente significativa, entre as transfusões sanguíneas e a mortalidade de pacientes graves internados em unidades de terapia intensiva. ${ }^{\prime 31}$

Desta forma, apesar de o avanço científico ter feito com que a técnica tenha se tornado mais segura do que era há alguns anos, ainda existem muitos riscos, o que faz com que mesmo pacientes não religiosos muitas vezes se recusem a receber transfusão, já que a ciência ainda não é capaz de eliminar todas as possíveis doenças relacionadas a ela.

\footnotetext{
${ }^{31}$ LIGIERA, Wilson Ricardo. Tutelas de Urgência na recusa de transfusão de sangue. In: Temas sobre tutela de urgência. Org. Pós-Graduação em Direito da Universidade Paulista - UNIP. São Paulo: Arte \& Ciência, 2002. p. 157-179.
} 


\section{Assim lembra Maria Helena Diniz:}

É preciso não olvidar que no estágio atual do conhecimento humano o sangue a ser transfundido raramente será $100 \%$ seguro, porque os testes disponíveis na esfera não só nacional, mas também mundial, não podem levar à segurança absoluta da ausência de risco para o paciente, pois, como é sabido na comunidade científica, sempre haverá a possibilidade de existência da chamada janela imunológica, que se caracteriza pela produção de testes com resultados falsos negativos, já que os atualmente à disposição algumas vezes não são capazes de detectar a presença de doenças transmissíveis pelo sangue em alguns portadores saudáveis, o que poderá ocorrer, por exemplo, com certos portadores do vírus da AIDS, cujos testes poderão não detectar a presença do vírus transmissor da patologia. ${ }^{32}$

Essa janela imunológica citada pela Autora refere-se a um período de tempo que o corpo leva, desde a infecção, para a criação de anticorpos contra um agente infeccioso, o que significa que, se realizado um teste para identificar determinada doença transmissível, como o vírus HIV, em um tempo inferior ao adequado, mesmo um indivíduo infectado pode apresentar um resultado negativo, ainda que falso.

Nos anos 80, o vírus da AIDS causou uma grande epidemia e gerou forte preocupação em relação à segurança das transfusões de sangue, visto que restou comprovado que "cerca de $2 \%$ dos casos de AIDS eram transmitidos por transfusão e mais de $50 \%$ dos hemofílicos apresentavam-se infectados pelo virus $H I V ", 33$

Foi em 1985 que finalmente se iniciaram os testes no sangue dos doadores a fim de se detectar a presença do vírus, mas o problema permanecia, pois eles não eram realizados nos sangues já estocados nos bancos antes do surgimento dos referidos testes, além de se revelar, posteriormente, a existência desse 'período de latência' da AIDS, que consiste na já explicada “janela imunológica", agravando o problema, como se explica:

\footnotetext{
32 DINIZ, Maria Helena. Op. Cit., p. 347.

33 JUNQUEIRA, Pedro C. et al.. História da Hemoterapia no Brasil. Revista Brasileira de Hematologia e Hemoterapia. 2005, vol.27, n.3, p. 206
} 
Depois de uma pessoa ser infectada, podem decorrer meses até que comece a produzir anticorpos detectáveis. Tal pessoa, sem se dar conta de que abriga o vírus, poderia doar sangue que daria resultado negativo nos testes. Isto já tem acontecido. Houve pessoas que manifestaram a AIDS depois de terem recebido uma transfusão de tal sangue! ${ }^{34}$

E a preocupação não se dá somente em relação ao período em que o vírus não se manifesta no corpo ou em relação à falta de verificação dos sangues anteriormente armazenados, ressaltando-se a insuficiência dos atuais testes para identificar o vírus em determinados casos, mesmo quando a doença já poderia ser detectada, porque o sistema de triagem não é perfeito:

Foi confirmado que pessoas podem abrigar o vírus da AIDS durante anos, sem este ser detectado pelos atuais testes indiretos. Alguns gostariam de minimizar tais casos, como sendo raros, mas estes provam "que os riscos de transmissão da AIDS via sangue e seus componentes não pode ser totalmente eliminado". (Periódico Patient Care, de 30 de novembro de 1989) A conclusão perturbadora é: Um teste negativo não pode ser entendido como um atestado de boa saúde. Quantos ainda contrairão a AIDS por meio de sangue ${ }^{35}$

É possível, da mesma forma, a ocorrência de erros administrativos nos bancos de sangue e que muitas vezes são determinantes para uma transfusão mal sucedida, existindo o risco, por exemplo, de uma confusão entre os tipos sanguíneos a serem utilizados ou na identificação da bolsa ou do paciente, ocorrendo reações hemolíticas fatais no caso de haver incompatibilidade do grupo $\mathrm{ABO}$ e do fator $\mathrm{Rh}$ no momento da transfusão. ${ }^{36}$

Há, ainda, a possibilidade de rejeição do sangue pelo sistema imunológico do receptor, estimando-se que, apenas nos EUA, seja a causa de morte de cerca de dez mil a cinquenta mil pacientes por ano ${ }^{37}$ :

\footnotetext{
${ }^{34}$ Como pode o sangue salvar a sua vida? São Paulo: Associação Torre de Vigia de Bíblias e Tratados, 1990. p. 12

${ }^{35}$ Ibid. p. 12.

${ }^{36}$ VANE, Luiz Antonio; GANEM, Eliana Marisa. Doação homóloga versus autóloga e substitutos da hemoglobina. In: CAVALCANTI, Ismar Lima et al.. Medicina perioperatória. Rio de Janeiro: Sociedade de Anestesiologia do Estado do Rio de Janeiro, 2006. p. 291-306.

37 Estratégias Alternativas à Transfusão: Simples, Seguras, Eficazes. VIDEO. Disponível em: <https://www.jw.org/pt/biblioteca-medica/videos/estrategias-alternativas-transfusao/> Acesso em: 11 de maio de 2018.
} 
Quem recebe sangue de outra pessoa corre basicamente os mesmos riscos dos que recebem um transplante de órgão. O sistema imunológico tem a tendência de rejeitar tecidos alheios. Em alguns casos, as transfusões de sangue na realidade impedem que as reações imunológicas naturais sejam ativadas. Tal imunossupressão deixa o paciente vulnerável a infecções pós-operatórias e a vírus antes inativos. ${ }^{38}$

Os efeitos podem incluir, ainda, a transmissão do HTLV I e II, um vírus da mesma família do HIV e que também ataca o sistema imunológico, mais especificamente os linfócitos $\mathrm{T}$, podendo provocar um tipo mais raro de leucemia, assim como paraparesia espástica, principalmente de músculos dos membros inferiores. ${ }^{39}$

Outros vírus passíveis de serem transmitidos são os das Hepatites B e C, além de ser comum a infecção por doenças parasitárias como a Doença de Chagas, a Sífilis e a Malária, sem deixar de se considerar a possibilidade do surgimento de novas doenças a qualquer tempo, até mesmo pela mutação dos vírus já existentes, o que torna ainda mais difícil o trabalho de detectar todos os agentes infecciosos existentes, como enfatizado pelo Dr. Harvey G. Klen:

E se surgisse um novo agente infeccioso que, tal como o da Aids, ficasse no corpo da pessoa muito tempo sem ser detectado e fosse facilmente transmitido por meio do sangue? Ao falar numa conferência médica em Praga, na República Tcheca, em abril de 2005, o Dr. Harvey G. Klein dos Institutos Nacionais de Saúde, dos EUA, disse que essa perspectiva é preocupante. Ele acrescentou: "Os que coletam componentes de sangue não estariam muito mais bem preparados para impedir uma epidemia transmitida por meio de transfusão de sangue do que estavam no princípio da Aids." ${ }^{40}$

Além dos problemas relacionados aos doadores de sangue contaminados pelas doenças e sua transmissão aos receptores, há também a questão da carência dos sistemas de saúde em realizar uma avaliação prévia do perfil sorológico

\footnotetext{
${ }^{38}$ Medicina transfusional - seu futuro está garantido?. In: Sangue — Por que é tão valioso?: Revista Despertai!. São Paulo: Associação Torre de Vigia de Bíblias e Tratados, 2006. p. 6.

${ }^{39}$ ROMANELLI, Luiz Cláudio Ferreira et al.. O vírus linfotrópico de células Thumanos tipo 1 (HTLV1): Quando suspeitar da infecção? Revista da Associação Médica Brasileira. 2010, vol.56, n.3, p. 342. ${ }^{40}$ Op. cit. p. 6.
} 
destes últimos antes da transfusão, o que contribuiria para adoção de medidas para minimizar a propagação das doenças em receptores que se mostrassem reativos no exame. ${ }^{41}$

Vane e Ganem adicionam à lista dos riscos algumas outras complicações possíveis no manuseio das transfusões de sangue, como a "intoxicação pelos produtos do anticoagulante, a hipotermia, a hiperpotassemia, as alterações ácido-base, a formação de microêmbolos, a queda da quantidade da enzima 2,3 $D P G,{ }^{42}$

Em razão de todos esses riscos, seja com relação à contaminação do sangue por doenças infecciosas, ou em razão da ineficiência dos meios atualmente existentes para detectar todos os agentes transmissíveis atuais e futuros, bem como complicações em decorrência da administração do sangue, a busca por meios alternativos à transfusão tem sido muito intensificada.

Tudo isso fez com que a preocupação com a hemoterapia seja cada vez mais uma questão de saúde pública, não só de crença religiosa, o que leva à necessidade de constantes pesquisas e o reconhecimento de novas técnicas de tratamento isentas de sangue, que sejam eficientes, seguras e em conformidade com as escolhas dos pacientes, em respeito às suas crenças, ao seu direito de autodeterminação, à sua privacidade e à sua saúde.

\subsection{Tratamentos Alternativos}

Além de todos os riscos já elencados que envolvem as transfusões de sangue, não se pode deixar de considerar os seus altos custos, tanto em relação aos esforços para manter as bolsas de sangue quanto aos gastos com a internação pós-transfusional conforme pesquisa realizada por Santos et al.:

\footnotetext{
${ }^{41}$ CARRAZZONE, Cristina F. V. et al.. Importância da avaliação sorológica pré-transfusional em receptores de sangue. Revista Brasileira de Hematologia e Hemoterapia. 2004, vol.26, n.2, p. 96.

${ }^{42}$ VANE, Luiz Antônio; GANEM, Eliana Marisa. Doação homóloga versus autóloga e substitutos da hemoglobina. Op cit. p. 295.
} 
Embora varie entre países, o preço estimado de uma bolsa de sangue, em 2010, nos Estados Unidos da América (EUA) chegava a US\$1200, quando consideradas todas as atividades envolvidas na transfusão de sangue. A transfusão de $\mathrm{CH}$ também foi associada a uma maior permanência hospitalar, resultando em aumento dos custos hospitalares. ${ }^{43}$

Há também o problema da escassez do sangue, já que a demanda é maior do que a oferta, o que leva mesmo pacientes que aceitam as transfusões com todos os seus riscos a ficarem sem a oportunidade de receber doações e dependentes de outros métodos.

As técnicas alternativas às transfusões de sangue, apesar de até hoje não serem muito utilizadas por grande parte dos médicos, existem há anos e têm se mostrado muito eficazes, com menos riscos do que a hemoterapia.

$\mathrm{Na}$ verdade, as cirurgias sem sangue já existiam mesmo antes de as transfusões se popularizarem, mas no início do século 20 a tecnologia das transfusões avançou em um nível que fez com que ela fosse propagada e utilizada por todo o mundo ${ }^{44}$, o que gerou um problema além dos riscos com a própria transfusão: a sua utilização desenfreada e muitas vezes desnecessária.

Durante a década de 70, ocorreu um aumento significativo no número de casos de Hepatite, levando muitos médicos a começarem a buscar alternativas aos tratamentos. Na década de 80, com a epidemia da AIDS, equipes médicas que já realizavam tratamentos sem sangue foram procuradas por outras que pretendiam seguir o mesmo caminho, em busca de evitar riscos que o sangue oferecia. Daí em diante, diversos hospitais desenvolveram programas de tratamentos alternativos às transfusões. ${ }^{45}$

Para auxiliar a relação entre médicos e pacientes Testemunhas de Jeová, existe um grupo de voluntários que formam as COLIH (Comissões de Ligações

${ }^{43}$ SANTOS, Antônio Alceu dos et al. Opções terapêuticas para minimizar transfusões de sangue alogênico e seus efeitos adversos em cirurgia cardíaca: Revisão sistemática: Revista Brasileira de Cirurgia Cardiovascular. São José do Rio Preto, v. 29, n. 4, p. 608, dec. 2014.

${ }^{44}$ A crescente procura por tratamentos médicos e cirurgia sem sangue. Revista Despertai!. São Paulo: Associação Torre de Vigia de Bíblias e Tratados, 2000. p. 8.

${ }^{45}$ A crescente procura por tratamentos médicos e cirurgia sem sangue. Op. Cit. p. 9. 
com Hospitais). As COLIH realizam pesquisas sobre estratégias clínicas para tratamentos sem sangue para ajudar os médicos, auxiliam assistência pastoral aos pacientes internados, facilitam contatos entre médicos especializados, realizam apresentações aos profissionais da área de saúde e jurídica e buscam esclarecer as questões éticas acerca dos tratamentos. ${ }^{46}$

No ano 2000, as COLIH começaram a distribuir à comunidade médica de todo o mundo um DVD intitulado "Alternativas à Transfusão - Série de documentários", contendo três vídeos em que diversos médicos expõem suas experiências com as Testemunhas de Jeová e a existência de diversas alternativas seguras, o que movimentou médicos, juristas, entre outros profissionais das áreas a aderirem aos métodos.

Um grande exemplo citado é o do dr. Denton Cooley, que em de maio de 1962 realizou a primeira cirurgia de coração aberto isenta de sangue em um paciente Testemunha de Jeová, o que é visto por muitos como o início da propagação dos tratamentos alternativos. Em 1977, o mesmo médico publicou um relatório contendo 542 cirurgias cardiovasculares sem sangue realizadas por ele, mostrando nível de risco de complicações muito baixo dessas cirurgias. ${ }^{47}$

Sobre as alternativas, as técnicas estratégicas clínicas e cirúrgicas isentas de sangue são principalmente três: tolerância à anemia, otimização da massa eritrocitária e diminuição da perda do sangue.

O limiar para a transfusão de sangue normalmente estabelecido é um nível de hemoglobina de $10 \mathrm{~g} / \mathrm{dL}$ (ou hematócrito de 30 por cento) para todos os pacientes. No entanto, experiências com pacientes que se recusam a receber sangue e estudos demonstraram que os níveis de hemoglobina toleráveis dependem do de pessoa para pessoa, podendo ser bem mais baixos. Santos et al. chegaram à essa mesma conclusão:

\footnotetext{
${ }^{46}$ Comissões de Ligação com Hospitais para as Testemunhas de Jeová. Associação Torre de Vigia de Bíblias e Tratados. Disponível em: 〈https://www.jw.org/pt/biblioteca-medica/estrategias-downloads/> Acesso em: 08 de maio de 2018.

${ }^{47}$ Estratégias Alternativas à Transfusão: Simples, Seguras, Eficazes. VIDEO. Op. Cit.
} 
A literatura evidencia que o ser humano é capaz de tolerar níveis extremamente baixos de hemoglobina. Graffeo et al. relataram um caso que, após um quadro de hemorragia grave e coagulação intravascular disseminada, chegou a um nadir mínimo de $1,9 \mathrm{~g} / \mathrm{dL}$ de hemoglobina. Em outro relato, após cirurgia de grande escoliose toraco-lombar, a paciente também sobreviveu sem uso de transfusão de sangue, mesmo após atingir nível crítico de $1,4 \mathrm{~g} / \mathrm{dL}$ de hemoglobina. Nestes dois casos, a tolerância à anemia foi uma opção terapêutica que resultou em economia de hemocomponentes para os bancos de sangue. ${ }^{48}$

Além disso, é importante que se faça cessar imediatamente a hemorragia em caso de perda muito grande do sangue, bem como que se proceda à otimização da oferta de oxigênio. Para isso, técnicas recomendáveis são o aumento do débito cardíaco, a reposição do volume do plasma para manter o fluxo circulatório, bem como a ventilação do paciente com altas frações inspiradas de oxigênio. ${ }^{49}$

Existem certos fluidos expansores de volume sem a utilização de sangue, tais como os cristaloides (tendo como exemplo a solução de lactato de Ringer) e os coloides (soluções de amido e gelatinas), que são muito mais viáveis do que a transfusão de sangue, por diversos motivos:

Tais líquidos apresentam vantagens definitivas. "Soluções cristalóides [tais como a solução salina normal e o lactato de Ringer], o Dextran e o HES são relativamente atóxicos e baratos, prontamente disponíveis, podem ser estocados à temperatura ambiente, não exigem testes de compatibilidade e estão isentos do risco de doenças transmitidas pela transfusão." — Blood Transfusion Therapy-A Physician's Handbook (A Terapia da Transfusão de Sangue — Manual do Médico), de 1989. ${ }^{50}$

É possível também influenciar uma minimização do consumo do oxigênio, o que pode ser feito de várias formas: com a utilização de analgésicos apropriados, sedação e relaxantes musculares, sedação mecânica e controle da

\footnotetext{
${ }^{48}$ SANTOS, Antônio Alceu dos et al.. Op Cit., p. 616.

${ }^{49}$ Ibid. p. 616-617.

${ }^{50}$ Como pode o sangue salvar a sua vida? Op. Cit., 1990. p. 14.
} 
temperatura corporal (aquecer ativamente pacientes hipotérmicos e resfriar pacientes febris). ${ }^{51}$

Com um planejamento anterior, é possível, ainda, otimizar a massa eritrocitária e o estado de coagulação do paciente antes de ser submetido a um procedimento cirúrgico, avaliando o histórico de anemia, medicamentos utilizados que podem ter feitos sobre ela, exames físicos e de sangue, bem como tratamentos para a anemia.

Para tratar a anemia, é importante avaliar a deficiência do ferro, que é a causa mais comum da doença. Sendo essa a causa, há diversas maneiras de se tratar. Vejamos:

Ferro intravenoso (IV), por infusão salina, como exemplo, o sacarato de hidróxido férrico (dose de 3 a $5 \mathrm{mg} / \mathrm{kg} /$ dia e máximo de $200 \mathrm{mg} / \mathrm{dia}$ ) ou a carboximaltose (dose $15 \mathrm{mg} / \mathrm{kg}$ e máximo de $1.000 \mathrm{mg}$ em infusão única) pode repor as reservas de ferro mais rápida. Pode-se aumentar a biodisponibilidade do ferro oral por meio de concomitante administração de ácido ascórbico. O uso simultâneo de produtos lácteos, gema de ovo, café, chá, antiácidos, ou fibra reduz a absorção do ferro oral. Recomendase uso de ferro parenteral em pacientes com intolerância ao ferro oral, absorção inadequada, ou perda de sangue crônica ou severa, ou nos casos de pacientes que não respondam ao tratamento. ${ }^{52}$

Outra forma comum e eficaz de se tratar a anemia é a utilização de eritropoietina humana recombinante (EPO) antes da cirurgia, pois ela aumenta a massa eritrocitária do paciente. Em casos de anemia grave, recomenda-se que seja feita em conjunto com a terapia de ferro para potencializar a resposta dos agentes eritropoiéticos. ${ }^{53}$

Durante uma cirurgia também existem diversas técnicas para diminuir a perda de sangue. Um exemplo é a preservação sanguínea intra-operatória e manejo do sangue autólogo, evitando procedimentos extremamente invasivos que causem maior perda sanguínea, utilizando-se, para isso, instrumentos

\footnotetext{
${ }^{51}$ SANTOS, Antônio Alceu dos et al. Op. Cit., p. 617.

${ }^{52}$ Ibid. p. 611.

${ }^{53}$ Ibid. p. 611.
} 
cirúrgicos hemostáticos, que são aqueles capazes de realizar menores lesões e diminuir a probabilidade de hemorragia, além de um controle rápido de hemorragia e utilização de agentes hemostáticos (são substancias que evitam a perda sanguínea, o tempo do ato cirúrgico, diminuem a drenagem pós-operatória e tempo de internação. ${ }^{54}$ )

Existem, ainda, técnicas cirúrgicas que envolvem a utilização do próprio sangue do paciente. É importante frisar que alguma delas não são aceitas por todos os pacientes Testemunhas de Jeová, como é o caso da Hemodiluição Normovolêmica Aguda (HNA), que armazena o sangue antes da cirurgia.

Outras, porém, não são expressamente proibidas, como é o caso do reaproveitamento intra-operatório do sangue, em que "O sangue coletado é misturado com anticoagulante, filtrado, lavado, concentrado e devolvido ao paciente. " 55 , bem como do aparelho coração-pulmão, utilizada durante cirurgias de coração aberto para circular o sangue fora do corpo.

Por não haver vedação clara na Bíblia, alguns cristãos aceitam esses tratamentos, desde que a circulação extracorpórea do sangue não se interrompa. Outros, porém, mantem a a posição de que se o sangue foi retirado do corpo, ele se torna inutilizado. Por isso, é dever do médico informar o paciente e manterse ciente de sua escolha. ${ }^{56}$

Nesse passo, nota-se que são muitas as opções à disposição das equipes médicas para que os tratamentos de pacientes Testemunhas de Jeová em casos de perda de sangue aguda sejam de acordo com suas convicções. As evidências mostram que essas técnicas são plenamente eficazes, mais baratas e causam menos riscos à saúde.

Ocorre que, apesar dos benefícios, os médicos ainda assim enfrentam muitas questões éticas e jurídicas ao tratar esses pacientes. Isso porque o nosso

\footnotetext{
${ }^{54}$ CARVALHO, Marcus Vinicius H. de et al . Agentes hemostáticos locais e adesivos teciduais. Revista Colégio Brasileiro de Cirurgiões, Rio de Janeiro, fev.2013, v. 40, n. 1. p. 66.

${ }^{55}$ SANTOS, Antônio Alceu dos et al. Op. Cit. p. 615.

${ }^{56}$ Como pode o sangue salvar sua vida? Op. Cit., p. 27.
} 
ordenamento jurídico não é expresso em relação à legalidade ou não da recusa à transfusão de sangue baseada em crenças religiosas, o que dá insegurança aos profissionais de saúde deixa os juristas a par de suas próprias interpretações acerca das regras e princípios aplicáveis ao caso, levando a uma diversidade de decisões conflitantes sobre um mesmo assunto.

Além disso, a dificuldade aumenta quando nos deparamos com casos de pacientes Testemunhas de Jeová que, apesar de seguirem a vida em conformidade com sua crença, se encontram inconscientes no momento em que se constata a necessidade da transfusão, ficando a pergunta: será que, sabendo de todos os detalhes de sua situação e as suas opções, o paciente em plena consciência ainda se recusaria a receber o sangue em respeito à sua religião?

Outras questões mais complexas são as que envolvem os pacientes menores de idade, visto que são plenamente incapazes e necessitam da autorização de seus responsáveis, levantando-se a questão acerca da validade da manifestação dos pais que se recusam a permitir a transfusão de sangue em seus filhos, quando este se encontra em iminente risco de vida. O mesmo problema se dá com relação às mães gestantes, visto que está em jogo o interesse de outra vida que não a sua. 


\section{Capítulo 3 - Casos Específicos}

\subsection{Pacientes Maiores e Capazes}

Antes de se passar à análise da situação em questão, é preciso ressaltar a ausência de previsão legal expressa que proíba a recusa à transfusão de sangue por pacientes maiores de idade e plenamente capazes de tomar decisões em relação à sua própria vida e ao seu próprio corpo. Assim, o que nos resta é um exame dos dispositivos existentes e que possam gerar insegurança no tratamento da situação.

Em segundo lugar, devemos lembrar do que já foi antes explicado em relação ao ilusório conflito de direitos que o caso propõe: o direito à vida e o direito à liberdade religiosa. Celso Ribeiro Bastos faz uma análise muito interessante do direito à vida disposto no texto constitucional, que é capaz de dissolver muitas interpretações equivocadas que o colocam em um pedestal como aquele que deve prevalecer sobre qualquer outro direito fundamental.

$\mathrm{O}$ autor ressalta que a $\mathrm{CRFB} / 88$ garante a inviolabilidade do direito à vida, o que demanda uma ação negativa do Estado e da sociedade, não interferindo no direito individual de cada um, mas não garante a sua indisponibilidade, que diz respeito somente à pessoa sujeito do direito em questão. Assim explica:

Insista-se, neste ponto, que a Constituição acaba por assegurar, tecnicamente falando, a inviolabilidade do direito à vida, assim como o faz quanto à liberdade, intimidade, vida privada, e outros tantos valores albergados constitucionalmente. Não se trata, propriamente, de indisponibilidade destes direitos. Realmente, não há como negar juridicidade a ocorrências nas quais pessoas se despojam inteiramente, v.g., de sua privacidade. Não se vislumbra qualquer cometimento de um ato contrário ao Direito em tais circunstâncias. Por inviolabilidade deve compreender-se a proteção de certos valores constitucionais contra terceiros. Já a indisponibilidade alcança a própria pessoa envolvida, que se vê constrangida já que não se lhe reconhece qualquer discricionariedade em desprender-se de determinados direitos. No caso presente, não 
se fala em indisponibilidade, mas sim de inviolabilidade. O que a Constituição assegura, pois, é a "inviolabilidade do direito à vida" (art. 5o, caput). ${ }^{57}$

Deste modo, é viável e aceitável que uma pessoa disponha de sua própria vida se assim desejar, pois a sua indisponibilidade não é vedada pelo nosso ordenamento, mas sim sua inviolabilidade. Quanto a isso, é importante ainda destacar que não se trata de uma hipótese de suicídio, no qual uma pessoa simplesmente decide deixar de viver por algum motivo. Pelo contrário, o objetivo dos Testemunhas de Jeová é ter garantido um direito de viver em conformidade com suas crenças e com seus valores éticos e morais, incluindose o direito de escolher tratamento isento de sangue ${ }^{58}$, o que, como vimos, é plenamente possível e existem diversas técnicas para isso.

Em que pese não haver previsão no ordenamento jurídico que proíba a objeção às transfusões de sangue, alguns dispositivos legais são comumente invocados para embasar os argumentos de que ao médico seria permitido intervir contra a vontade do paciente em caso de risco de vida, e que a recusa seria ilegal, gerando responsabilidades para o profissional que respeite a manifestação de seu paciente consciente e capaz.

$\mathrm{O}$ art. 146, § $3^{\mathrm{a}}$, inciso I do Código Penal dispõe que não se encontra na hipótese do crime de constrangimento ilegal "a intervenção médica ou cirúrgica, sem o consentimento do paciente ou de seu representante legal, se justificada por iminente perigo de vida". Apesar de isentar o médico de pena caso realize a transfusão, esse é o alcance máximo que se pode dar a esse artigo, que não responsabiliza o médico caso deixe de realizar a transfusão de sangue.

Luís Roberto Barroso, ao formular um parecer acerca dos aspectos jurídicos da questão, destaca a supremacia da Constituição sobre as demais leis, que daria margem até mesmo à uma interpretação do artigo em conformidade

\footnotetext{
${ }^{57}$ BASTOS, Celso Ribeiro. Direito de recusa de pacientes, de seus familiares ou dependentes, às transfusões de sangue, por razões científicas e convicções religiosas. São Paulo: Parecer Jurídico, 2000. p. 9.

${ }^{58}$ Ibid.
} 
com ela, limitando a sua aplicação às hipóteses em que a obtenção do consentimento livre e esclarecido do paciente em risco de vida não seja possível. ${ }^{59}$

Poder-se-ia argumentar o contrário para criminalizar a conduta do médico, alegando o disposto no art. 135 do Código Penal, segundo o qual, incorre em crime de omissão de socorro aquele que deixar de prestar assistência "à pessoa inválida ou ferida, ao desamparo ou em grave e iminente perigo; ou não pedir, nesses casos, o socorro da autoridade pública".

No entanto, o caso em questão não se refere à ausência de prestação de socorro. Na verdade, como visto, o que se espera de um profissional de saúde, por parte dos pacientes Testemunhas de Jeová, é a devida prestação médica, mas que ela seja feita sem o uso de sangue, razão pela qual os médicos devem utilizar todos os seus esforços para o bem do paciente, tendo como limite a autonomia individual deste.

Deste modo, não há omissão de socorro se o médico, em respeito ao direito de autodeterminação do paciente, atua nos limites permitidos pela crença religiosa deste a fim de garantir a dignidade da pessoa humana, fundamento máximo do Estado Democrático de Direito.

Além disso, já não bastasse a falta de punição legal e a garantia constitucional à liberdade de crença e de consciência como direitos fundamentais, há previsão no que diz respeito ao respeito à autonomia do indivíduo, inclusive no Código Civil, nem seu art. 15, segundo o qual "Ninguém pode ser constrangido a submeter-se, com risco de vida, a tratamento médico ou a intervenção cirúrgica."

A interpretação desse artigo é objeto de muitas controvérsias sobre o que significaria a expressão "com risco de vida". No entanto, é razoável observar

\footnotetext{
${ }^{59}$ BARROSO, Luís Roberto. Legitimidade da recusa de transfusão de sangue por Testemunhas de Jeová. Dignidade Humana, liberdade religiosa e escolhas existenciais. Rio de Janeiro: Parecer Jurídico. 2010. p. 353.
} 
que o artigo não visa à manutenção da vida a qualquer custo, não corroborando a disseminada ideia de que o direito à vida é absoluto e é condição para o exercício de qualquer outro direito fundamental.

Pelo contrário, o artigo, admitindo a possibilidade dos riscos do tratamento, consagra a autonomia do paciente para recusar o procedimento, e deste modo, também deve ser interpretado no sentido de respeitar a escolha individual da pessoa, que, devidamente livre e após suficientemente informada, seja fundada em "motivos que não sejam fúteis e que se fundem na afirmação da própria dignidade. "60

O direito individual à autodeterminação do paciente Testemunha de Jeová também foi consagrado pelo Tribunal de Minas Gerais, em 2007, no julgamento de um Agravo de Instrumento que tratava de um paciente diagnosticado com câncer no sistema linfático, em que se alegava que a quimioterapia seria muito agressiva ao sistema imunológico do paciente e a transfusão de sangue serviria para aumentar seus níveis de hemoglobina. Destaca-se, aqui, um trecho do voto do Relator, que foi acompanhado pelos demais Desembargadores:

\begin{abstract}
Aparentemente, a direito à vida não se exaure somente na mera existência biológica, sendo certo que a regra constitucional da dignidade da pessoa humana deve ser ajustada ao aludido preceito fundamental para encontrar-se convivência que pacifique os interesses das partes. Resguardar o direito à vida implica, também, em preservar os valores morais, espirituais e psicológicos que se lhe agregam. Faço esta observação, porquanto a recepção de sangue pelo seguidor da corrente religiosa Testemunhas de Jeová o torna excluído do grupo social de seus pares e gera conflito de natureza familiar que acaba por tornar inaceitável a convivência entre seus integrantes. Cria-se, portanto, um ambiente no qual a pessoa é tida como religiosamente indigna e que não merece a necessária acolhida em seu meio, como descrito em doutrina. É necessário, portanto, que se encontre uma solução que sopese o direito à vida e à autodeterminação que, no caso em julgamento, abrange o direito do agravante de buscar a concretização de sua convicção religiosa, desde que se encontre em estado de lucidez que autorize concluir que sua recusa é legítima. Sim, porque não há regra legal alguma que ordene à pessoa natural a obrigação de submeter-se a tratamento clínico de qualquer natureza; a opção de tratar-se com especialista objetivando a cura ou o controle de determinada doença é ato voluntário de quem é dela portador, sendo certo que, atualmente, o recorrente encontra-se em alta hospitalar e não há preceito normativo algum que o obrigue a
\end{abstract}

\footnotetext{
${ }^{60}$ TEPEDINO, Gustavo et al.. Código Civil interpretado conforme a Constituição da República, vol.1,
} $2^{\mathrm{a}}$ ed.. Rio de Janeiro: Renovar, 2007. p. 42. 
retornar ao tratamento quimioterápico se houver a perspectiva de ocorrer a transfusão sanguínea. ${ }^{61}$

Como se observa, o Relator também deixou clara a inexistência de regra jurídica que obrigue o paciente a se submeter a qualquer tratamento contra a sua vontade, corroborando a interpretação acima dada ao art. 15 do Código Civil, assim, mesmo com risco de vida é lícito que alguém se recuse a ser submetido a determinado tratamento médico.

Além disso, obrigar um paciente que buscou auxilio médico a receber transfusão de sangue se torna ainda mais injusto se pensamos na situação daqueles que nem ao menos buscaram ajuda, e que desta forma não terão sua liberdade de crença, sua autonomia e sua dignidade violadas, enquanto os que tentam encontrar uma solução acabam sendo prejudicados.

Isso é importante até mesmo para se considerar a possibilidade de muitos Testemunhas de Jeová passarem a se recusar a buscar qualquer tipo de tratamento médico por medo de terem sua crença desrespeitada, o que causa o risco de aumentar o número de mortes $^{62}$ que poderiam ser facilmente evitadas se as equipes médicas começassem a levar mais em consideração a pluralidade de valores éticos e morais existentes, abraçando as diversas estratégias alternativas à transfusão que estão à sua disposição há anos.

Outro caso, julgado em 2016 pelo TRF da $1^{\mathrm{a}}$ Região, tratava de uma mulher diagnosticada com Leucemia Linfoblástica Aguda - LLA, que também precisava se submeter à quimioterapia, e o Hospital requereu a imposição de transfusão de sangue por apresentar quadro de anemia. ${ }^{63}$

O acórdão ressalta que a paciente era adulta e capaz, e que foi devidamente esclarecida acerca do seu estado de saúde e dos tratamentos

\footnotetext{
${ }^{61}$ TJMG - Agravo de Instrumento n ${ }^{\mathrm{o}}$ 1.0701.07.191519-6/001. Relator: Des. Alberto Vilas Boas, $1^{\mathrm{a}}$ Câmara Cível, Minas Gerais. Julgado em 14/08/2007.

${ }^{62}$ BASTOS, Celso Ribeiro. Op. Cit., p. 24.

${ }^{63}$ TRF-1 - Agravo de Instrumento no 0017343-82.2016.4.01.0000. Relator: Des. Federal Kassio Nunes

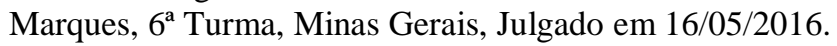


disponíveis, optando tanto verbalmente quanto por meio de documento de diretivas antecipadas por um tratamento isento de sangue, ante à existência de técnicas alternativas que já estavam sendo ministradas pelas equipes médicas.

Nesse caso, é possível até mesmo notar como a questão muitas vezes é levada ao judiciário sem nem ao menos haver fundamento para tanto. Isso porque, no caso em questão, estava à disposição dos médicos a eritropoietina, que como já explicado, é uma alternativa segura e eficaz para o tratamento da anemia, assim como muitas outras existentes. Ao pesquisar sobre o assunto, Ligiera já havia chegado a essa mesma observação:

Em alguns casos investigados, muito embora fosse afirmado na petição inicial que transfundir o paciente era imprescindível para a manutenção de sua vida, tal procedimento acabou não sendo realizado, mostrando-se por fim desnecessário. $\mathrm{O}$ enfermo teve sua saúde restabelecida com a utilização de alternativas médicas sem sangue. Por outro lado, nas hipóteses em que os pacientes realmente corriam risco de vida, o procedimento transfusional não foi capaz de salvá-los. Destarte, já não se pode aceitar o raciocínio simplório de que transfusão é sinônimo de vida. ${ }^{64}$

Assim, vemos que é dever das equipes médicas estarem atentas à real necessidade de uma transfusão de sangue, evitando ao máximo chegar a essa opção ao lidarem com pacientes que a recusem e, não havendo outra possibilidade, que se respeite a sua autonomia, pautada no direito fundamental à liberdade de crença e de consciência.

Outro caso muito interessante foi julgado também em 2016 no Tribunal de Justiça do Pará. Em primeira instância, foi ajuizada ação por paciente Testemunha de Jeová que apresentava problemas cardíacos e necessitava de cirurgia, mas o estado em que residia não apresentava recursos para um procedimento sem sangue, razão pela qual requereu tutela antecipada para ser transferida a um hospital em Piauí, onde poderia realizar a cirurgia de acordo com suas convicções, que foi concedida, resultando no recurso pelo Estado.

${ }^{64}$ LIGIERA, Wilson Ricardo. Op Cit. 
No caso apresentado, a Relatora manteve a decisão de primeiro grau, enfatizando a necessidade de se ter um sistema de saúde garantidor, que seja acessível a toda a população, e que questões orçamentárias não podem servir como óbice à realização de direitos constitucionalmente garantidos:

A saúde é um direito humano fundamental, constituindo-se um direito público subjetivo da pessoa para exigir do "Estado", uma atividade prestacional que assegure o acesso universal e igualitário, com atendimento integral. Quando a Constituição Federal incluiu a saúde no seio dos direitos fundamentais, impôs ao Estado uma atuação positiva de assegurar esse acesso. O particular tem o direito público subjetivo de exigir ou não a atividade estatal.

(...)

Assim, o direito à liberdade religiosa, como um direito fundamental, deve o Estado assegurar o tratamento de saúde resultante de escolha religiosa ou crença, como no presente caso. Havendo alternativa ao procedimento cirúrgico tradicional, não pode o Estado recusar o Tratamento Fora do Domicílio (TFD) quando ele se apresenta como única via que vai ao encontro da crença religiosa da paciente.

Enfatizo que no presente caso, o Estado não está sendo obrigado a disponibilizar tratamento de saúde diferenciado, mas apenas providenciar a remessa de documentos necessários para a realização do procedimento cirúrgico no Estado do Piauí. Por derradeiro, no tocante à arguição sobre a falta de dotação orçamentária, entendo que essa questão por si só, não serve para afastar o cumprimento de suas obrigações constitucionais, que é salvaguardar a vida de todo e qualquer ser humano, máxime quando inexistirem provas robustas acerca da falta de orçamento. ${ }^{65}$

No entanto, apesar de haver justificativa o bastante para se respeitar a liberdade religiosa dos pacientes Testemunhas de Jeová, até o momento estamos nos referindo a pacientes maiores de idade e em plena capacidade mental, o que lhes dá o poder de autodeterminação, se devidamente informados das consequências desses atos. Agora, então, passaremos a tratar das situações em que o paciente, apesar de ser maior de idade, encontra-se em risco de vida e inconsciente, estando incapacitado se expressar a sua vontade.

\footnotetext{
${ }^{65} \mathrm{TJPA}$ - Agravo de Instrumento $\mathrm{n}^{\circ}$ 0041659-07.2014.8.14.0301. Relatora: Desembargadora Célia
} Regina de Lima Pinheiro, 2a Câmara Cível Isolada, Pará, Julgado em 03/11/2016. 


\subsection{Pacientes Inconscientes}

Quando nos deparamos com situações de extrema urgência em que o paciente encontra-se inconsciente e não há como obter a sua autorização para realizar a transfusão de sangue, é comum que os médicos procurem seus familiares para explicar a situação.

Nesse caso, temos duas hipóteses: a primeira é considerarmos que as Testemunhas de Jeová normalmente vêm de uma família que compartilha da mesma crença e frequentam a mesma comunidade, o que faz com que estes logo refutem a possibilidade se transfusão de sangue no paciente inconsciente, ainda que não se tenha conhecimento da real vontade deste.

A segunda hipótese é o caso em que o paciente carrega consigo um documento de Diretiva Antecipada de Vontade, o que normalmente ocorre com esses cristãos. Por meio de tal documento, o indivíduo previamente esclarece ser Testemunha de Jeová e manifesta a expressa recusa à transfusão de sangue, bem como a autorização para realizar tratamentos alternativos.

O primeiro caso é mais simples de se chegar a uma conclusão, pois estando o paciente inconsciente e sem documentação que comprove sua crença, não há como saber a sua vontade se não por meio de familiares e amigos. Nessa situação, ainda que a família queira decidir por ele no sentido de recusar a transfusão de sangue, o médico não deve levar as manifestações em consideração, pois nesse caso prevalece a inviolabilidade da vida constitucionalmente garantida, que significa que não cabe a terceiros decidir pelo destino de uma vida alheia.

Como já vimos, a legalidade de uma decisão se verifica quando o paciente é adulto, capaz e em pleno gozo de suas faculdades mentais no momento da manifestação, devendo a própria pessoa decidir para si após esclarecida de seus riscos e suas alternativas. Não sendo assim, a transfusão deve ser feita, pois 
assim como a vida, a autonomia existencial também não é absoluta, e o seu limite é a intervenção na esfera de terceiros, como afirma Dworkin:

Um Estado não precisa aceitar a afirmação de um membro devoto das Testemunhas de Jeová, por exemplo, de que o seu parente inconsciente preferiria não receber uma transfusão de sangue que o faria recuperar a consciência - mesmo que o Estado aceitasse essa decisão caso o paciente estivesse consciente. Mas, em nossa opinião, a vida e a saúde têm uma importância tão fundamental que ninguém deve ter o poder de rejeitá-las em nome de outra pessoa. ${ }^{66}$

O segundo caso já é objeto de maiores controvérsias. As Testemunhas de Jeová portam um documento chamado "Diretivas Antecipadas e Procuração Para Tratamento de Saúde”. Nele, elas expressam sua recusa à transfusão de sangue e dispõem instruções sobre diversos outros tratamentos de saúde. Constam ainda, as assinaturas do paciente, de duas testemunhas e de dois procuradores que deverão garantir os interesses expressos na declaração. Ressalte-se, ainda, que tal documento é registrado em cartório.

Quando constatada a presença dessa declaração, predeterminando a objeção à realização de transfusão de sangue, a discussão passa a ser se essa declaração é válida ou não, visto que se trata de uma manifestação anterior ao risco de morte.

Celso Ribeiro Bastos, entendendo pela validade, fundamenta-se nos requisitos de validade dos negócios jurídicos presentes no art. 82 do Código Civil de $1916^{67}$, cuja redação foi reproduzida quase inteiramente pelo art. 106 do Código Civil atualmente vigente ${ }^{68}$. Assim dispõe em seu parecer:

\footnotetext{
${ }^{66}$ DWORKIN, Ronald, O Direito da Liberdade: a leitura moral da Constituição norte-americana. Trad. Marcelo Brandão Cipolla, 2006, p. 215. Apud PRATA, Claudia Alves. As Testemunhas de Jeová e a discriminação no acesso a tratamentos isentos de sangue. Revista Eletrônica de Direito Público, nov.2016, vol. 3, n. 2.

${ }^{67}$ Art. 82. A validade do ato jurídico requer agente capaz, objeto lícito e forma prescrita ou não defesa em lei.

${ }^{68}$ Art. 104. A validade do negócio jurídico requer:

I - agente capaz;

II - objeto lícito, possível, determinado ou determinável;

III - forma prescrita ou não defesa em lei
} 
Em termos de manifestação de vontade, há de se atentar apenas para os requisitos de sua validade, ou seja, agente capaz, objeto não proibido pelo Direito e forma prescrita em lei. No caso presente, cumpre acentuar que não se trata de objeto proibido pelo Direito, antes sendo decorrência direta do princípio da liberdade. ${ }^{69}$

De fato, o documento portado pelas Testemunhas de Jeová não contém nenhum objeto ilícito, já que apenas dispõe acerca dos tratamentos permitidos por eles, em expressa manifestação de sua autonomia. Assim também se posiciona Fabio leite:

De fato, tratando-se de paciente maior e capaz, mas inconsciente, deve-se ao máximo buscar identificar a sua vontade se este se encontrasse no gozo de suas faculdades mentais (doutrina do substituted judgement), em respeito "à individualidade e à dignidade de uma pessoa que, enquanto era capaz, havia expressado suas inequívocas, profundamente sentidas e inclusive sagradas preferências, mas que no momento não tem capacidade para decidir" (como frisou a Corte de Apelação di Distrito de Columbia, caso In re Boyd). ${ }^{70}$

Em conformidade com os princípios aqui sempre defendidos da dignidade da pessoa humana e da autonomia existencial, além de se analisar se a declaração cumpre todos os requisitos legais de validade, é necessário que se busque observar as condutas praticadas por aquele individuo durante toda a sua vida, principalmente naqueles momentos mais próximos do estado de inconsciência, em busca de se confirmar que sua declaração corresponde com as suas expectativas.

É compreensível o receio das equipes médicas em respeitar um documento previamente escrito, pois existe sempre a possibilidade de uma pessoa, dependendo da situação em que se encontra, mudar a sua opinião para continuar vivendo, abdicando de suas crenças religiosas. No entanto, a declaração dos Testemunhas de Jeová é documento hábil a eximir os médicos de qualquer responsabilidade, sendo uma prova de que foi realizado autonomamente por pessoa adulta, consciente e capaz. Assim, o mais apropriado

\footnotetext{
${ }^{69}$ BASTOS, Celso Ribeiro. Op. Cit., p. 29.

${ }^{70}$ LEITE, Fábio Carvalho. Op. Cit., p. 435.
} 
é que se respeite a sua vontade, se se constatar que ela está em conformidade com os princípios seguidos pela pessoa durante sua existência.

\subsection{Pacientes Menores de Idade e Gestantes}

A questão da recusa ao tratamento com transfusão de sangue pelos pais de pacientes menores de idade nos remete necessariamente a uma análise do poder familiar. A família, ao lado da sociedade e o Estado, tem o dever legal de proteger a vida do menor, assim dispondo a CRFB/88:

Art. 227. É dever da família, da sociedade e do Estado assegurar à criança, ao adolescente e ao jovem, com absoluta prioridade, o direito à vida, à saúde, à alimentação, à educação, ao lazer, à profissionalização, à cultura, à dignidade, ao respeito, à liberdade e à convivência familiar e comunitária, além de colocá-los a salvo de toda forma de negligência, discriminação, exploração, violência, crueldade e opressão.

O Estatuto da Criança e do Adolescente, no seu art. $4^{\circ}$, reitera a obrigação constitucional, com texto muito similar:

Art. $4^{\circ}$ É dever da família, da comunidade, da sociedade em geral e do poder público assegurar, com absoluta prioridade, a efetivação dos direitos referentes à vida, à saúde, à alimentação, à educação, ao esporte, ao lazer, à profissionalização, à cultura, à dignidade, ao respeito, à liberdade e à convivência familiar e comunitária.

Não só isso. O ECA ainda dispõe expressamente acerca da necessidade de se garantir o desenvolvimento da criança e do adolescente, dando-lhes todas as oportunidades para isso por meio da proteção integral de todos os seus direitos fundamentais:

Art. $3^{\circ} \mathrm{A}$ criança e o adolescente gozam de todos os direitos fundamentais inerentes à pessoa humana, sem prejuízo da proteção integral de que trata esta Lei, assegurandose-lhes, por lei ou por outros meios, todas as oportunidades e facilidades, a fim de lhes facultar o desenvolvimento físico, mental, moral, espiritual e social, em condições de liberdade e de dignidade. 
A proteção integral dos direitos e interesses do menor fundamenta-se na dignidade da pessoa humana. Isso significa que é dever da família zelar pelo desenvolvimento completo do menor, que, além de ainda não ser fisicamente e mentalmente maduro, não construiu inteiramente os seus valores morais, culturais, éticos, políticos, entre outros.

Um caso muito emblemático sobre uma menor de idade foi o julgamento do Habeas Corpus $n^{\circ}$ 268.459. Tratava-se de uma menina de 13 anos portadora da doença anemia falciforme, e o único tratamento possível era a transfusão de sangue, que foi rejeitada pelos pais em razão de sua crença religiosa.

Os pais da menina foram pronunciados pelos crimes tipificados nos arts. 121, caput e 61, inciso II, “e”, ambos do Código Penal11, razão da impetração da medida judicial no STJ.

O Ministro Rogério Schietti Cruz, em seu excelente voto, destaca a já discutida aparente colisão de direitos fundamentais, lembrando que não há hierarquia entre eles, então para a solução justa de cada caso concreto, é a dignidade da pessoa humana que deve ser considerada na escolha do direito a prevalecer:

O fato de estarem insertos no campo dos valores não permite ao magistrado agir com total discricionariedade na escolha entre os princípios concorrentes, devendo ser eleito aquele que mais se aproxima da dignidade da pessoa humana, fundamento do Estado Democrático de Direito (art. $1^{\circ}$, inciso III da Constituição Federal), essa sim com valor absoluto. $^{72}$

O ministro ainda ressalta que o poder familiar deve ser voltado ao bemestar dos filhos, sem considerar os interesses próprios, ainda que fundamentados em crença religiosa, e ainda explica:

\footnotetext{
${ }^{71}$ Art. 121. Matar alguém.

Art. 61 - São circunstâncias que sempre agravam a pena, quando não constituem ou qualificam o crime: II - ter o agente cometido o crime: e) contra ascendente, descendente, irmão ou cônjuge;

${ }^{72}$ STJ - HC no 268.459. Relatora: Ministra Maria Thereza de Assis Moura, $6^{a}$ Turma, Brasília, Julgado em 02/09/2014, DJe: 28/10/2014.
} 
O direito à vida, o mais fundamental de todos os direitos, não é absoluto, disso não me olvido. Sem, também, perder de vista que não há hierarquia entre direitos fundamentais, entendo que a hipótese dos autos não deixa espaço para mitigação do direito à vida, pois o embate enredava a vida de uma adolescente, cuja obrigatoriedade de proteção pelos pais encontrava-se constitucionalmente resguardada, moralmente desejada e naturalmente imposta. ${ }^{73}$

Assim, o Estado, na qualidade de guardião dos direitos das crianças e dos adolescentes junto com a família, ainda que deva respeitar a autodeterminação das pessoas, deve intervir nessa autonomia quando o seu exercício verse sobre a vida de terceiros, principalmente quando os terceiros são pessoas incapazes e que precisam de absoluta proteção. Thamis Dalsenter compartilha dessa mesma opinião, ao tratar dos limites da autonomia individual:

De acordo com as restrições da autonomia por razões de consciência, assinala-se que independente da liberdade de escolha e das suas íntimas convicções, o sujeito não pode fazer do exercício da sua autonomia um risco à esfera jurídica de terceiros. Assim, no exemplo apresentado sobre a recusa de tratamento médico de Testemunhas de Jeová, convém assinalar que a objeção de consciência da mãe não é capaz de conferir o corpo do filho como campo de sua própria autonomia, de modo que o tratamento médico deverá ser implementado, sob pena de abuso do poder familiar. ${ }^{74}$

Sobre o abuso do poder familiar nesse caso, pode-se explicá-lo a partir do princípio do dano abordado por Kipper, que ocorre quando, ao recusar um tratamento imprescindível à saúde do menor, os pais não estão apenas contrariando os sues interesses, mas com isso ainda colocam a sua vida em risco, causando-lhe um dano que torne tais decisões intoleráveis, devendo o Estado atuar para prover os cuidados necessários ao bem-estar a ao desenvolvimento desses indivíduos vulneráveis. Assim explica:

O princípio provê a base capaz de identificar o limite para a intervenção do Estado. A característica da decisão parental que justifica a intervenção não é aquela que contraria os melhores interesses da criança, mas a que pode lhe causar mal ou dano. As autoridades terão então legitimada sua intervenção em duas situações, ambas

\footnotetext{
73 Ibid.

${ }^{74}$ CASTRO, Thamis Dalsenter Viveiros de. Bons Costumes no Direito Civil Brasileiro. São Paulo: Almedina, 2017. p. 92.
} 
preenchendo os critérios do princípio do dano: 1) A intervenção deve ser baseada na doutrina do parens patriae, isto é, o Estado tem autoridade para proteger e cuidar aqueles que não o podem fazer por si mesmos, podendo intervir quando existe evidência de que as decisões dos pais podem causar mal aos seus filhos; 2) A intervenção pode ser justificada como exercício de vigilância para a proteção da saúde da população ou de outros. ${ }^{75}$

Deve-se levar em consideração, aqui, a hipótese plenamente possível de um menor de idade vir a discordar de seus pais e responsáveis quanto às suas crenças. As pessoas são únicas, cada uma com suas características próprias, e ainda que estejam inseridas em um ambiente familiar voltado às mesmas convicções, elas não estão imunes às diferentes opiniões externas.

Assim, somando o pluralismo da sociedade em que vivemos com o incentivo do Estado, da família e da sociedade na formação de indivíduos com personalidade e caráter próprios, é certo que, até que a formação psicofísica de um indivíduo o torne apto a tomar decisões por si mesmo, é obrigação da família garantir sua segurança para que tenha a oportunidade de viver de acordo com seus próprios valores, em respeito à dignidade da pessoa humana, único princípio que deve prevalecer em caráter absoluto, mas que tem significados diversos para cada indivíduo.

O caso das pacientes gestantes é um pouco mais complicado. Primeiro, porque a própria gravidez já é uma agravante no que se refere aos riscos de hemorragia, e segundo, porque, ao recusar a transfusão de sangue, estamos lidando com duas vidas, a da paciente e a do seu filho.

Nessa situação, adotando a mesma linha de pensamento dos pacientes menores de idade, não vejo saída para a equipe médica senão proceder à transfusão de sangue, ainda que contra a vontade da mãe. Quando uma pessoa se compromete em dar prosseguimento a uma gravidez, ela está adquirindo a responsabilidade pela vida de uma segunda pessoa, e ainda que se pudesse

\footnotetext{
${ }^{75}$ KIPPER, Délio José. Limites do poder familiar nas decisões sobre a saúde de seus filhos - diretrizes. Revista Bioética, 2015, vol. 23, nº 1. p. 45.
} 
invocar o princípio da autonomia da vontade da paciente, como ficaria a interrupção de uma outra vida, que ela mesma decidiu trazer ao mundo, em razão de crenças religiosas próprias?

Apesar de não se considerar o direito à vida mais importante do que a liberdade religiosa, pois são ambos direitos fundamentais dispostos na $\mathrm{CRFB} / 88$, quando se invoca uma crença para interromper a vida de outra pessoa, o que se deve pensar é em garantir a possibilidade de esse ser obter as próprias crenças, garantindo-lhe um nascimento com vida e saudável.

Importante frisar que não estamos diante de uma situação de aborto, na qual se fala em toda uma questão de saúde pública decorrente de milhares de mortes por procedimentos precários aos que as mulheres se submetem, o que ensejaria uma análise muito mais profunda dos direitos das mulheres em interromper a gravidez. Aqui, estamos falando de mulheres com vontade e capacidade de criar um filho, mas situadas em um estado de emergência, e no momento de salvar a vida que se comprometeram a criar, optam por deixar a criança morrer para não viverem com a culpa de terem desrespeitado seus princípios.

Assim, não há diferença de uma mãe grávida para uma mãe com filhos menores, pois no momento em que decide ter aquele filho, ela já é responsável pela criança, e não há crença religiosa que possa ensejar a inviolabilidade de outra vida, principalmente quando se tem o dever legal de protegê-la. 


\section{Conclusão}

O presente trabalho teve como objetivo avaliar o caso dos pacientes professantes da religião Testemunhas de Jeová nas hipóteses em que necessitam da transfusão de sangue para tratamento, mas se recusam a recebê-la em razão de sua crença religiosa.

Em primeiro lugar, analisamos a liberdade religiosa e sua manifestação no direito brasileiro desde a Constituição Imperial de 1824 até a Constituição atualmente vigente, passando de uma Constituição expressamente católica para uma laica, que garante a liberdade de crença, consciência e culto.

Abordamos, então, os argumentos das Testemunhas de Jeová para justificar a objeção de consciência no que se refere às transfusões de sangue, que se baseia em interpretações de diversas passagens bíblias, tratando o sangue como um elemento sagrado e que representa a própria vida dos seres humanos, e somente Jeová tem poder sobre ele, não cabendo à medicina manipular o sangue dado por Ele a seus fiéis.

Para auxiliar nas relações entre médicos e pacientes Testemunhas de Jeová, vimos como adequada a aplicação dos princípios bioéticos da beneficência, não-maleficência e autonomia. Tais princípios vêm ganhando mais espaço e atenção desde a descoberta dos experimentos abusivos com seres humanos no período pós-guerra, quando a sociedade finalmente percebeu que os indivíduos estavam sendo injustamente submetidos às condutas desumanas, sem que ao menos tivessem consentido para tanto.

Esses princípios, em conjunto com a necessidade de se garantir a dignidade da pessoa humana a todos, foram sendo aplicados também às relações entre médicos e pacientes, a fim de se elevar esses últimos como seres dotados de autonomia e capacidade decisiva sobre seu corpo e sua vida, afastando condutas paternalistas dos médicos para se respeitar o direito de autodeterminação do indivíduo. 
Dentro desse contexto de autodeterminação, passamos então ao estudo dos riscos decorrentes da prática das transfusões. Em razão do sangue apresentar diversos riscos à saúde e à própria vida, que foram detalhadamente apresentados, a recusa à sua utilização deixa de ser apenas uma questão exclusiva da liberdade religiosa de alguns, para ser uma questão de saúde para todos, pois vimos que as transfusões de sangue são utilizadas se forma desenfreada e nem sempre são a melhor técnica, sendo, na verdade, responsáveis pela transmissão de inúmeras doenças, além da possibilidade de ocorrerem diversas reações pelo receptor.

Vimos, então, que existem diversas alternativas às transfusões, que são até mesmo mais seguras e eficazes, sendo utilizadas há anos com resultados satisfativos, o que é capaz de diminuir a ultrapassada ideia acerca da necessidade de transfusão para salvar a vida, entendendo-se, agora, que ela é uma mera tentativa de reverter um quadro clínico, assim como são os outros tratamentos, pois a medicina não é uma ciência exata e ainda está em desenvolvimento.

Assim, a conduta dos médicos, apesar de ser no sentido de salvar a vida dos pacientes, tem como limite a liberdade do indivíduo de decidir pelo seu corpo, aceitando ou não determinados tratamentos. Mas essa autonomia é condicionada à uma decisão devidamente esclarecida, no qual o paciente é informado de todos os seus ricos, bem como só é válida se tomada por indivíduos adultos e capazes, em pleno gozo de suas faculdades mentais.

Se no caso concreto, então, estivemos diante de um paciente maior de idade, capaz, consciente, e esclarecido de sua condição, tendo a transfusão de sangue como última alternativa possível, ainda que o paciente esteja em risco de morte, é dever dos médicos respeitar sua decisão. Isso porque não existe hierarquia entre direito à vida e direito à liberdade religiosa, e nesse caso concreto a crença religiosa é o próprio fundamento da vida, é o que a faz ser digna para aquele determinado indivíduo.

Quando esses pacientes, ainda que adultos e capazes, encontram-se em estado de inconsciência, deve-se observar se há alguma disposição autônoma 
desse indivíduo no sentido de ver garantida a sua crença em caso de estar em perigo de vida. Não havendo nada além de relatos dos familiares ou de sua comunidade, não há prova alguma de que, diante de tal situação, a pessoa continuaria a invocar a sua fé para recusar tratamentos que forem indispensáveis a salvar a sua vida.

Por outro lado, estando presente algum documento que o identifique como Testemunha de Jeová e disponha sobre as Diretivas Antecipadas de tratamentos, expressamente vedando a transfusão de sangue, ainda que em caso de risco de morte, não existe motivo para que os médicos desrespeitem sua vontade. O que se deve observar é se o documento foi escrito por agente capaz (sendo ele o próprio paciente), se tem objeto lícito e se sua forma está prescrita em lei ou não seja vedada por ela.

Já nos casos dos menores de idade, estamos diante de pacientes incapazes, em estágio de desenvolvimento psicofísico, que não estão aptos à tomar decisões maduras por si mesmos, sendo responsabilidade de seus pais decidirem sobre os atos da vida civil. No entanto, a autonomia dos pais sobre a vida dos filhos tem limite na CRFB/88 e no ECA, que garantem o desenvolvimento das crianças e dos adolescentes, garantindo que tenham a oportunidade de construir o próprio futuro, com os próprios valores. É por isso, aliás, que a liberdade de crença e de consciência não se estende aos filhos que ainda estão por nascer, mas já concebidos e correndo risco de vida.

Portanto, conclui-se que a liberdade de crença deve ser observada e respeitada quando versa sobre a própria pessoa que a invoca, ainda que seja a causa de sua morte, desde que esta esteja ciente da sua escolha e seja plenamente capaz para decidir deste modo, mas quando os direitos alheios são violados, a autonomia é limitada em prol de garantir a dignidade da pessoa humana de todos, que é construída a partir da sua convivência com a pluralidade de valores existentes na sociedade. 


\section{Bibliografia}

ASSOCIAÇÃO TORRE DE VIGIA DE BÍBLIAS E TRATADOS. Testemunhas de Jeová: Proclamadores do Reino de Deus. São Paulo, 1993.

ASSOCIAÇÃO TORRE DE VIGIA DE BÍBLIAS E TRATADOS. $O$ que $a$ Bíblia realmente ensina? São Paulo, Cesário Lange, 2005.

A crescente procura por tratamentos médicos e cirurgia sem sangue. Revista Despertai!. São Paulo: Associação Torre de Vigia de Bíblias e Tratados, 2000.

BARROSO, Luís Roberto. Legitimidade da recusa de transfusão de sangue por Testemunhas de Jeová. Dignidade Humana, liberdade religiosa e escolhas existenciais. Rio de Janeiro: Parecer Jurídico. 2010.

BASTOS, Celso Ribeiro. Direito de recusa de pacientes, de seus familiares ou dependentes, às transfusões de sangue, por razões científicas e convicções religiosas. São Paulo: Parecer Jurídico, 2000.

CARRAZZONE, Cristina F. V. et al.. Importância da avaliação sorológica prétransfusional em receptores de sangue. Revista Brasileira de Hematologia e Hemoterapia. 2004, vol.26, n.2.

CARVALHO, Marcus Vinicius H. de et al. Agentes hemostáticos locais e adesivos teciduais. Revista Colégio Brasileiro de Cirurgiões, Rio de Janeiro. fev.2013, v. 40, n. 1.

CASTRO, Thamis Dalsenter Viveiros de. Bons Costumes no Direito Civil Brasileiro. São Paulo: Almedina, 2017 
CLOTET, Joaquim. Bioética: uma aproximação. Porto Alegre: EDIPUCRS, 2003, 246p.

Comissões de Ligação com Hospitais para as Testemunhas de Jeová. Associação Torre de Vigia de Bíblias e Tratados. Disponível em: <https://www.jw.org/pt/biblioteca-medica/estrategias-downloads/> Acesso em: 08 de maio de 2018.

Como pode o sangue salvar a sua vida? São Paulo: Associação Torre de Vigia de Bíblias e Tratados, 1990.

DINIZ, Maria Helena. O estado atual do biodireito. $10^{\mathrm{a}}$ ed.. São Paulo: Saraiva, 2017.

Estratégias Alternativas à Transfusão: Simples, Seguras, Eficazes. VIDEO. Disponível em: <https://www.jw.org/pt/biblioteca-medica/videos/estrategiasalternativas-transfusao/> Acesso em: 11 de maio de 2018.

JUNQUEIRA, Pedro C. et al.. História da Hemoterapia no Brasil. Revista Brasileira de Hematologia e Hemoterapia. 2005, vol.27, n.3.

KIPPER, Délio José. Limites do poder familiar nas decisões sobre a saúde de seus filhos - diretrizes. Revista Bioética, 2015, vol. 23, nº 1.

KIPPER, Délio José; CLOTET, Joaquim. Princípios da Beneficência e Nãomaleficência. In: COSTA, Sérgio Ibiapina Ferreira et al.. Iniciação à bioética. Brasília: Conselho Federal de Medicina, 1998. p. 37-51. 
LEITE, Fábio Carvalho. Estado e Religião: A Liberdade Religiosa no Brasil. Curitiba: Juruá, 2014. 488p.

LEVI, Guido Carlos; BARROS, Antonio Ozório Leme de. Ética clínica: a AIDS como paradigma. In: COSTA, Sérgio Ibiapina Ferreira et al.. Iniciação à bioética. Brasília: Conselho Federal de Medicina, 1998. p. 285-294.

LIGIERA, Wilson Ricardo. Tutelas de Urgência na recusa de transfusão de sangue. In: Temas sobre tutela de urgência. Org. Pós-Graduação em Direito da Universidade Paulista - UNIP. São Paulo: Arte \& Ciência, 2002. p. 157-159.

LOPES, José Agostinho. Bioética - uma breve história: de Nuremberg (1947) a Belmont (1979). Revista Médica de Minas Gerais. 2014, vol. 24, n. 2.

MARIANO, Ricardo. Secularização do Estado, liberdades e pluralismo religioso. Disponível em: <http://www.equiponaya.com.ar/congreso2002/ponencias/ricardo_mariano.ht m > Acesso em: 23 de Abril de 2018.

MUÑOZ, Daniel Romero; FORTES, Paulo Antônio Carvalho. O princípio da autonomia e o consentimento livre e esclarecido. In: COSTA, Sérgio Ibiapina Ferreira et al.. Iniciação à bioética. Brasília: Conselho Federal de Medicina, 1998. p. 53-70.

MURAMOTO, Osamu. Bioethics of the refusal of blood by Jehovah's Witnesses: Part 2. A novel approach based on rational non-interventional paternalism. J Med Ethics, 1998, Oct. 24. 
NAMBA, Edison Tetsuzo. Manual de Bioética e Biodireito. $2^{\mathrm{a}}$ ed.. São Paulo: Atlas, 2015.

PRATA, Claudia Alves. As Testemunhas de Jeová e a discriminação no acesso a tratamentos isentos de sangue. Revista Eletrônica de Direito Público, nov.2016, vol. 3 , n. 2.

Quais são as crenças principais das Testemunhas de Jeová? Associação Torre de Vigia de Bíblias e Tratados. Disponível em: <https://www.jw.org/pt/testemunhas-de-jeova/perguntas-frequentes/crencastestemunhas-de-jeova/> Acesso em: 03 de maio de 2018.

Quem são as Testemunhas de Jeová? Revista A Sentinela, São Paulo: Associação Torre de Vigia de Bíblias e Tratados, 2015, vol.136, n.17.

ROMANELLI, Luiz Cláudio Ferreira et al.. O vírus linfotrópico de células $T$ humanos tipo 1 (HTLV-1): Quando suspeitar da infecção? Revista da Associação Médica Brasileira. 2010, vol. 56, n.3.

Sangue - Por que é tão valioso? Revista Despertai!. São Paulo: Associação Torre de Vigia de Bíblias e Tratados, 2006.

SANTOS, Antônio Alceu dos et al.. Opções terapêuticas para minimizar transfusões de sangue alogênico e seus efeitos adversos em cirurgia cardíaca: Revisão sistemática: Revista Brasileira de Cirurgia Cardiovascular. São José do Rio Preto; dec. 2014, v. 29, n. 4.

TEPEDINO, Gustavo et al.. Código Civil interpretado conforme a Constituição da República, vol.1, $2^{\mathrm{a}}$ ed.. Rio de Janeiro: Renovar, 2007. 790p. 
VANE, Luiz Antonio; GANEM, Eliana Marisa. Doação homóloga versus autóloga e substitutos da hemoglobina. In: CAVALCANTI, Ismar Lima et al.. Medicina perioperatória. Rio de Janeiro: Sociedade de Anestesiologia do Estado do Rio de Janeiro, 2006. p. 291-306.

STJ - HC n ${ }^{\circ}$ 268.459. Relatora: Ministra Maria Thereza de Assis Moura, $6^{\mathrm{a}}$ Turma, Brasília, Julgado em 02/09/2014, DJe: 28/10/2014.

TJMG - Agravo de Instrumento $\mathrm{n}^{\mathrm{o}}$ 1.0701.07.191519-6/001. Relator: Des. Alberto Vilas Boas, $1^{\text {a }}$ Câmara Cível, Minas Gerais, Julgado em 14/08/2007.

TRF-1 - Agravo de Instrumento nº 0017343-82.2016.4.01.0000. Relator: Des. Federal Kassio Nunes Marques, $6^{\mathbf{a}}$ Turma, Minas Gerais, Julgado em 16/05/2016.

TJPA - Agravo de Instrumento $\mathrm{n}^{\circ}$ 0041659-07.2014.8.14.0301. Relatora: Desembargadora Célia Regina de Lima Pinheiro, $2^{\mathrm{a}}$ Câmara Cível Isolada, Pará, Julgado em 03/11/2016. 